\title{
Seniority: A Blessing or A Curse? The Effect of Economics Training on the Perception of Distributive Justice
}

\author{
İbrahim Erdem SEÇİLMİŞ \\ ies@ hacettepe.edu.tr
}

\section{Kıdemli Öğrenci Olmak: Bir Lütuf Mu Yoksa Bir Lanet Mi? İktisat Eğitiminin Dağıtıcı Adalet Algısı Üzerine Etkisi}

\begin{abstract}
This paper examines the impact of the level of economics knowledge on the perception of equity in a Rawlsian sense when distributional issues are of concern to the students at different stages of their education. The purpose is to question the widely held belief that economics teaching has an influence on ethical views of individuals. To examine the relationship between fairness judgments and the level of the economics education, I use a survey-type experimental design, originally developed by Gaertner (1992), in which six different situations are investigated. By carrying out the questionnaire survey among both undergraduate and graduate students of public finance, I find that a clear learning effect does not exist. However, on the other hand, I cannot conclude against the indoctrination hypothesis in favor of the self-selection hypothesis; because the study seeks only to achieve a better understanding of the learning effect. Moreover, my results suggest that personal features, parental background and future income expectations of the students are mostly not strong variables enough to affect the response patterns.

Keywords

JEL Classification Codes

Distributive Justice, Rawlsian Approach, Economics Training, Learning Effect.$$
\text { A13, A20, D63. }
$$

Özet

$\mathrm{Bu}$ çalışma, eğitim sürecinin farklı evrelerinde yer alan öğrencilerin dağıtımsal meselelere ilişkin görüşlerini dikkate alarak, iktisat bilgisi seviyesinin Rawlscı eşitlik algısı üzerine etkisini araştırmaktadır. İlgili kapsamda amaç iktisat öğretiminin bireylerin etik görüşleri üzerinde etkili olduğunda dair genel kanının geçerliliğini sorgulamaktır. Bu çerçevede çalışmada adalet yargısı ve iktisat eğitimi seviyesi arasındaki ilişkiyi incelemek için Gaertner (1992) tarafından altı farklı durumu araştırmak amacıyla geliştirilen anket tipi deneysel tasarım kullanılmıştır. Maliye Bölümü lisans ve lisansüstü öğrencileri üzerinde gerçekleştirilen uygulama sonucunda açık bir öğrenme etkisi gözlemlenmemiştir. Ancak çalışma öğrenme etkisi üzerine odaklandığı için aktarılan sonuç endoktrinasyon hipotezi karşında öz-seçim hipotezi lehine bir destek olarak algılanmamalıdır. Ek olarak; sonuçlar öğrencilerin kişisel özelliklerinin, ebeveyn niteliklerinin ve gelecekteki gelir beklentilerinin çoğunlukla cevap kalıplarını etkileyecek güçlü değişkenler olmadığını işaret etmektedir.
\end{abstract}

\section{Anahtar Sözcükler \\ Dağıtıcı Adalet, Rawlscı Yaklaşım, İktisat Eğitimi, Öğrenme Etkisi.}


İbrahim Erdem SEÇILILIŞ

\section{Acknowledgement}

I would like to thank Professor Wulf Gaertner for his helpful comments on earlier versions of this article.

\section{Beyan}

Bu makaleye görüş ve önerileri ile sağladığı katkılardan dolayı Profesör Wulf Gaertner'e teşekkürü bir borç bilirim. 


\section{Introduction}

The concept of justice has always been a highly active area of research that is at the forefront of social sciences. Scholars from various fields and with different interests, including politics, economics, law, and sociology, have debated over issues concerning equity, fairness and social welfare so as to provide a clear-cut understanding of what justice actually means, what it requires and where it comes from. However, so far, considerable difficulties have been encountered in trying to find a common approach in order to put an end to controversies. In particular, many economists are focused on distributional problems when the issue is justice. The point of distributive justice - from the perspective of economic theory- is deriving criteria for assessing/ranking of distributions of income.

Utilitarianism as a powerful approach to normative ethics has dominated welfare economics for over a century. From the classical utilitarianism of Bentham (1789) and Mill (1861) to its modern formulation in terms of expected utility theory, which is inspired by Harsanyi (1953; $1955 ; 1977 ; 1978)$, utilitarianism as a normative approach has been the official theory of welfare economics (Sen 2000: 63, author's emphasis). Harsanyi and Vickrey (1945; 1960) propose social welfare justifications, based on a utilitarian social welfare function which focuses on the preferences of an impartial and sympathetic observer, for the adoption of the equiprobability assumption. As noted by Harsanyi (1975: 598), this assumption can be regarded as an application of the principle of indifference and/or an expression of a moral principle. By this way, individuals who make social decisions, from behind a "veil of ignorance" (henceforth VOI) ${ }^{1}$ without knowing their own social and economic positions in society, would maximize expected utility.

However, over the past decades many criticisms arose over the generalizability of the utilitarian theory. John Rawls, perhaps, who broke through the dominance of utilitarianism, is foremost among the critics. Rawls's A Theory of Justice (1971) is an attempt to develop a systematic contractarian approach. Rawls's concept of justice as fairness suggests an alternative to the familiar utilitaristic approach in welfare economics. Although individuals choose from behind VOI in the Rawlsian setting as well, the welfare of the worst-off members of society would be maximized (known as the "difference principle") instead of considering the sum of personal welfares.

Until recently, many researchers who have focused on various aspects/contexts of distributive justice have identified several differences/factors as having an effect on the perception of distributive justice. In the pioneer study of Yaari and Bar-Hillel (1984), the authors examined the effects of different contexts related to background, such as needs, tastes, beliefs, legitimate claims, and so forth, on judgements by using experimental data. The empirical works of Frohlich and Oppenheimer $(1992 ; 1994)$ and Konow $(2000 ; 2001)$ provided a discussion on the relationship between perception of justice within different frameworks concerning contextual effects and accountability, efficiency, and needs principles. Other scholars (see, e.g., Fleurbaey 1998; Fleurbaey and Maniquet 2011; Gaertner and Schwettmann 2007; Schokkaert and Capeau 1991; Schokkaert and Devooght 2003; Schokkaert and Overlaet 1989) focused on the issues related to the analysis of attributions concerning responsibility. In addition to problems at the stake and environmental factors, 
some other empirical studies (see, e.g., Gaertner and Jungeilges 2002; Gaertner et al. 2001; Gaertner et al. 2011; Jungeilges and Theisen 2008) explored the dependence of the distributional issues on the personal characteristics, cultural background, experience, etc.

The aim of this study is not only to check whether individuals' choices do conform to Rawls's "difference principle", but also to investigate the impact of the education level on the expression of the Rawlsian approach to distributive justice. Therefore, I conduct an empirical examination of the fulfillment of Rawls's "difference principle" by using a questionnaireexperimental approach, originally developed by Gaertner (1992). My goal is to make a contribution to this work by studying the influence of stage in economics education with a data set from Turkey.

The organization of the paper is as follows. Section 2 summarizes related literature and develops a foundation for my empirical tests. The theoretical framework is provided in Section 3. Next, Section 4 details the features of the situations. Section 5 explains the data collection process and describes the sample. Subsequently, Section 6 contains descriptive results. Section 7 presents the regression analysis and discussions. Finally, Section 8 draws some concluding remarks.

\section{Review of the Relevant Literature}

\subsection{Rawlsian Approach to Distributive Justice}

In A Theory of Justice (1971), John Rawls constructs an alternative to utilitarianism by developing a social contract theory consists of two principles which are needed to make judgements of justice. The basic liberties (e.g., freedom of thought and liberty of conscience, freedom of the person, and political liberty) are guaranteed by the first principle of justice. He claims that "each person has an equal right to the most extensive scheme of equal basic liberties compatible with a similar scheme of liberties for all" (Rawls 1974: 142). The principles are serially treated with the first principle having lexicographic priority ${ }^{2}$ over the second principle. The second principle has two parts and can be stated as, "social and economic inequalities are to meet two conditions: they must be (i) to the greatest expected benefit of the least advantaged members of society (the maximin equity criterion) and (ii) attached to offices and positions open to all under conditions of fair equality of opportunity" (Rawls 1974: 142)3.

Most economists tend to focus on the first component of the second principle, the maximin equity criterion. Rawls's maximin criterion, also known as the "difference principle" of distribution stresses that "unless there is a distribution that makes both persons better off... an equal distribution is to be preferred" (Rawls 1971: 76).

Rawlsian approach is distinguished from utilitarianism in a particular way. He develops an index of primary social goods (that includes rights and liberties, power and opportunity, income and wealth, and the social bases of self-respect) which is used as the appropriate measure of relative well-being ${ }^{4}$. In this context, Rawls conducts a thought experiment designed to address the selection of a principle of distributive justice. In the "original position" as a part of the his thought experiment,

\footnotetext{
For a detailed explanation of the notion of "lexicographic order" and its use, see Fishburn (1974).

(ii) takes priority over (i).

4 Dworkin (1981a; 1981b) uses a similar argument.
} 
Rawls believes that people behind a VOI would not know in advance their station in society (i.e., wealth, power, personal abilities, tastes, position within the social order of society) and would always choose the "difference principle" that could maximize the welfare of the worst-off". Both Harsanyi and Rawls agree to view the "original position" as a hypothetical experiment where a VOI shields individuals from "knowing their own social and economic positions, their own special interests in the society, or even their own personal talents and abilities (or their lack of them)" (Harsanyi 1975: 594). However, unlike Harsanyi, Rawls also believes that -in the "original position"- "since inequalities of birth and natural endowment are undeserved, these inequalities are to be somehow compensated" (Rawls 1971: 100) in a manner that is to the greatest advantage of the worst-off.

Some experimental studies have been conducted to test the feasibility of the Rawlsian approach to judgements on social welfare (see, e.g., Bond and Park 1991; dela Cruz-Dona and Martina 2000; Frohlich and Oppenheimer 1990; Frohlich and Oppenheimer 1992; Frohlich et al. 1987a; Frohlich et al. 1987b; Herne and Suojanen 2004; Jackson and Hill 1995; Lissowski et al. 1991; Oleson 2001; Schildberg-Hörisch 2010; Swope et al. 2008). In addition, several scholars have been studied on the implementation of VOI in the laboratory (see, e.g., Beckman et al. 2002; Carlsson et al. 2003; Johannesson and Gerdtham 1995; Johansson-Stenman et al. 2002; Traub et al. 2009; Traub et al. 2005). It is not only experimental studies that have contributed to our knowledge about distributive justice; but also survey/questionnaire studies yield this phenomenon (see, e.g., Amiel et al. 2009; Bernasconi 2002; Bosmans and Schokkaert 2004; Faravelli 2007; Gaertner 1994; Gaertner and Jungeilges 2002; Gaertner et al. 2001; Gaertner et al. 2011; Gaertner and Schokkaert 2011; Jungeilges and Theisen 2011).

Previous research in this area has shown mixed results in regards to the context, principle, method, etc. Some studies show that preferences/choices are not strictly consistent with any particular approach to distributive justice ${ }^{6}$. In addition, some other researchers find little evidence that there is a predictable behavior pattern which characterizes an individual's perception of justice. Furthermore, there is some support for the choice of a mixture of the maximin equity criterion and expected utility theory as a principle. Utilitarian justice approach with a floor constraint has been preferred by individuals in several studies (see, e.g., dela Cruz-Dona and Martina 2000; Frohlich and Oppenheimer 1990; Frohlich et al. 1987a; Herne and Suojanen 2004; Lissowski et al. 1991; Oleson 2001; Traub et al. 2005).

\subsection{Economics Training}

As it is emphasized in Section 1, the perception of fairness ${ }^{7}$ is not only related to contextual framework but also to the other factors including experience, beliefs, background, economics training, etc. Most previous studies in the field of economics education have examined the "economist effect" 8 and have dealt with the difference between economists and the rest of the

It might be better to interpret this approach according to the Rawls's Kantian framework.

For a theoretical discussion, see Giraud and Renouard (2011); and Kariv and Zame (2008).

7 The terms "fairness" and "justice" are used interchangeably in this study. There are some differences between two concepts for sure. However, they are ignored in this research for the sake of simplicity and clarity.

8 The term "economist effect" was used by Ledyard (1995). 
population, whereas the number of the studies have tended to focus on difference within the same discipline has remained limited.

The experimental literature up to 1995 is surveyed by Ledyard (1995). He reviewed experimental results on "the culture of economics" in order to find out whether a person's educational background has a substantial impact upon her/his behavioral attitudes. He reported five observations (Carter and Irons 1991; R. H. Frank et al. 1993; Isaac et al. 1985; Kagel et al. 1992; Marwell and Ames 1981), including public goods games, ultimatum games, and prisoner's dilemma games, compared the results and concluded that "the effect of training and/or self-selection ${ }^{10}$ on cooperation remains a wide-open problem"11 (Ledyard 1995: 161). The results of these papers have encouraged some further research using experimental approach (see, e.g., Bolton and Ockenfels 2006; Büchner et al. 2003; Engelmann and Strobel 2004; Engelmann and Strobel 2006; Fehr et al. 2006; R. H. Frank et al. 1996; Ockenfels and Weimann 1999; Selten and Ockenfels 1998). Furthermore, several field experiments/surveys/studies have been conducted in order to overcome the problem of external validity (see, e.g., Faravelli 2007; Frey and Meier 2003; Laband and Beil 1999; Yezer et al. 1996) ${ }^{12}$. The different motivations behind participation, cooperation, selfishness and altruism encountered in these papers make it difficult to see conclusively what causes the differences between the results of above-mentioned investigations. Therefore, the discussion on indoctrination and selection gives no clear answers and the debate is still wide open.

Although the number is small, there is a bunch of existing works and approaches which look at the influence of training in economics at the different stages of economics education. Frey et al. (1993) survey three different groups in a set-up based on situations of excess demand, and they find that "learning and practicing economics has no influence on the attitudes of students toward the fairness of prices increases" (Frey et al. 1993: 279). In general, the results of their survey contradict the indoctrination and confirm the effect of selection hypothesis. However, the paper of Haucap and Just (2010), almost using the same setting, comes to the opposite conclusion, finding that there are both nature and nurture effects ${ }^{13}$.

B. Frank and Schulze (2000) conduct an experiment to investigate determinants of corruptibility. In the paper, they provide evidence that supports the self-selection hypothesis. Their

9 The term "the culture of economics" was used by Amiel and Cowell (1999).

10 Due to concern with economic incentives before exposure to education in economics, one might self-select into economics. Undoubtedly, my research opens the way to the investigation of other topics such as the self-selection that was mentioned in the previous sentence. However, because this work focuses on the basic relationship between the stage effect of economics training and the perception of fairness, I cannot treat the selection hypothesis and related literature in detail here due to the lack of space.

11 The two conjectures may be called respectively the learning and selection hypotheses (Carter and Irons 1991). But regardless of what definition/name is offered in different studies (e.g., self-selection/indoctrination, selection/learning, nature/nurture, and background/education), the main question (except minor details) is whether the behavioral differences between economists and non-economists are stemmed from training or from selection. For this reason, all of the terms mentioned above are used interchangeably in this study.

12 For a more interdisciplinary perspective (economics and sociology), see Hu and Liu (2003); and Zsolnai (2003). For further survey research, see Frey and Pommerehne (1993); and Rubinstein (2006). For a review of the literature that focuses on "(why) economists are different”, see Kirchgassner (2005, author's emphasis).

13 Cipriani et al. (2009) report a similar result in their study on students' view on profit maximization and the market mechanism. 
results indicate that student attitudes towards corruption are the same, regardless of their seniority. Frey and Meier's study (2005) uses an administrative data set on student donations that allows to test the indoctrination hypothesis. They find additional evidence that the voluntary contributions of economists do not differ with respect to different levels of economics knowledge. Their results support the positive impact of self-selection on behavior. A similar finding is also reported in the experimental paper of Cappelen et al. (2010). Their data show only a small difference in the weight attached to fairness between business freshman and senior students. Following Frey and Meier $(2003)^{14}$, Bauman and Rose (2011) analyze a data set, consisting of each student's voluntary contributions to social cases, to examine the generosity of the economists. The aim of their study is to observe the relationship between student donations and microeconomics training over time. As in Frey and Meier (2003), they find that there is not an indoctrination effect for economics majors.

By using survey data from freshman and senior students, Faravelli (2007) investigates the influence of context and education on the perception of fairness. His results demonstrate that a learning effect exists for the economic students who prefer the "difference principle" to the egalitarian solution ${ }^{15}$. This finding is in contradiction with the results reported by Carter and Irons (1991) and R. H. Frank et al. (1993).

In a recent study by Gaertner et al. (2011), it is checked that whether an individual's perception of justice is dependent of the demands of the maximin equity criterion. They use a questionnaire-experimental approach to focus on the differences across cultures and over time. Their questionnaires are given to both graduates and undergraduates from economics and business administration. They find that graduate students have a stronger preference for the restoration of basic rights ${ }^{16}$ and report that economics knowledge, in particular in the field of distributive justice, might influence the perception of equity ${ }^{17}$.

In sum, as a result of different settings/frameworks/objectives, it is difficult to establish an unambiguous conclusion about the stage effect of economics education on the perception of distributive justice. Unfortunately, the results obtained so far do not permit one to make clear conclusions about the implications of the learning hypothesis and the self-selection hypothesis.

\section{The Theoretical Framework: An "Equity Axiom"}

The central problem encountered in comparing alternative approaches to distributive justice is finding an ethical ranking over the set of distributions. However, to figure out the problem

14 For similar settings/studies, see Benz and Meier (2008); and Frey and Meier (2004a; 2004b; 2005).

15 Bellemare et al. (2008) find that young and highly educated-highest vocational training or university education-people have a weaker preference for income equality. To estimate a model of decision making under uncertainty, Bellemare et al. (2008) conduct an ultimatum game and, though the structure of their model is very different from studies reviewed here in several ways, their results indicate that young and highly educated individuals have lower inequity aversion than other groups under study.

16 As it is mentioned before, Rawls's list of primary social goods includes not only income and wealth but also rights and liberties.

17 In addition, they report an inconsistency between the findings of their research and an unpublished study from Norway which finds that first-year students in business administration demonstrate stronger support for basic rights than third-year students. 
raised by the first sentence of this section, it is first necessary to have an idea about what one should expect from an interpersonal ranking rule. The preference of different maxims of equity plays a significant role in the differentiation of the theories of justices. As the conditions and features fulfilled by ranking rules- differ, different equity axioms come into agenda as well ${ }^{18}$.

Gaertner (1992) presents a theoretical model to study whether and to which extent individuals accept the Rawlsian "difference principle"19. He places an "equity axiom", which focuses on the maximin equity criterion, in the center of his analysis of distributive justice. The basic idea of the "equity axiom" is discussed by Sen (1973), Hammond (1976), D'Aspremont and Gevers (1977) and Deschamps and Gevers (1978). In the "equity axiom", there is a particular demand for a society where only two individuals are affected by a change from one policy to another. Each individual has to choose between policy $x$ (social state $x$ ) and policy $y$ (social state $y$ ). The basic postulate behind the axiom is the following: Individual is better off under $x$ than under $y$, while individual is better off under $y$ than under $x$ and the utility of individual is always higher than the utility of individual independently of the social state chosen eventually. In such situation, the "equity axiom" requires policy $x$ to be socially preferred to policy.

In Gaertner (1992), the "equity axiom" is used as an attempt to check whether individual welfare judgements are guided by the Rawlsian "difference principle" and, if it is the case, to observe whether the pursuit of the principle of maximizing the welfare of the worst-off members of society by individuals is unconditional. The maximin equity criterion corresponds to an infinite inequality aversion (Gaertner and Schokkaert 2011). To explore whether it is always followed by all individuals, Gaertner (1992) makes a suggestion on how to determine the degree of concavity of the interpersonal ranking rule (her/his desired degree of equity-orientation) as a measure of the equity aversion. Consider a two individual profile of so-called extended orderings $\widetilde{R_{\mathrm{i}}}, \hat{i} \in\{1,2\}$, denoted by $E^{1}$ :

\section{$\widetilde{R_{1}}:(y, 2)(x, 2)(x, 1)(y, 1)$. $\widetilde{R_{2}}:(y, 2)(x, 2)(x, 1)(y, 1)$.}

The following interpretations can be drawn from these lines:

a. There is a unanimous view that it is best to be individual under social state $y$ for both individuals.

b. Being individual under social state $y$ is better than being individual under social state ${ }^{x}$.

\footnotetext{
18 There are several axioms in the social choice literature such as follows: viz., independence of irrelevant alternatives, strong Pareto principle, anonymity, minimal equity, etc.

19 For subsequent studies, see Gaertner and Jungeilges (2002); Gaertner et al. (2001); and Gaertner and Schwettmann (2007).
} 
c. Being individual under social state $x$ is better than being individual under social state $\boldsymbol{X}$.

d. Being individual under social state $x$ is better than being individual under social state $y$.

e. Individual is always better off.

Considering the "equity axiom", social state ${ }^{x}$ will be declared as socially preferable to social state $y$. Next Gaertner enlarges the basic profile by adding the extended orderings of further individuals, by this way, keeping the structure of $E^{\mathbf{1}} \cdot E^{\mathbf{2}}$ (three individual profile of extensive orderings), for example, is:

\section{$\widetilde{R_{1}}:(y, 3)(x, 3)(y, 2)(x, 2)(x, 1)(y, 1)$, $\widetilde{R_{2}}:(y, 3)(x, 3)(y, 2)(x, 2)(x, 1)(y, 1)$, $\widetilde{R_{a}}:(y, 3)(x, 3)(y, 2)(x, 2)(x, 1)(y, 1)$.}

The main expectation is that, for the individuals who adopt the "equity axiom", social state $x$ should be the preferred state in situation $E^{\mathbf{1}}$. When just one individual is taken into focus, the fundamental question which arises in connection with the equity concerns asks whether her/his preference is the same for $E^{\mathbf{z}}$. If it is the case, one might ask a further question about how long the individual remains resistant despite the different situations $E^{3}, E^{\mathbf{4}}, \ldots$ Obviously, two answers are possible, depending on the equity perception of the individual: Either the individual's preference would always be in favor of social state $\boldsymbol{X}$-socially- (which means the unconditional pursuit of the "equity axiom"), or the individual would like to switch her/his choice from social state ${ }^{X}$ to social state $y$-socially- in a breakpoint ${ }^{20}$.

\section{The Situations}

In the previous section, some profiles of extended orderings, $E^{\mathbf{1}}, E^{\mathbf{2}} \ldots$, are considered which are characterized by a particular structure. I investigate six different situations (see Table 1), developed by Gaertner (1992), to examine in an empirical way the relationship between equity

20 For the aggregation problem arising from different switching points in a society and the relationship between society's degree of equity orientation and the issue at the stake, see Gaertner (1992). 
judgements and the level of the economics education, using a dataset collected from students who are enrolled in the different years ${ }^{21}$.

The structure of the situations is designed similarly to the above-mentioned profiles by Gaertner in order to analyze the perception of justice. His design is chosen intentionally due to the following reasons: First, it allows to check whether individuals follow the Rawlsian "difference principle". Second, the situations that reflect different aspects of needs offer the opportunity to evaluate individual behavior in a multidimensional way. Third, the detailed structure of the setup, which is easy to understand for subjects, tends to overcome the external validity 22 problem by allowing participants to make judgements about contexts/issues that are not entirely unfamiliar to them. In addition, the level of correspondence between Gaertner's survey-type experimental design and real world settings minimizes the concerns raised by the application of the approach and the robustness of the results.

In each situation, there is always one (group of) individual(s) who is always worst-off regardless of the social state chosen. That individual is better off under social state $\boldsymbol{X}$ than under social state, while all the other (groups of) individuals are better off under social state $y$ than under social state ${ }^{X}$. First of all, the respondents have to solve a baseline decision making problem in each situation $^{23}$. The six situations, given in Table 1, are briefly explained below ${ }^{24}$ :

- Situation 1: First, Situation 1 (henceforth S1) requires a decision between helping a handicapped person (social state $\boldsymbol{X}$ ) or teaching an intelligent child (social state $y$ ). In the second, third and fourth steps, social state $x$ is the same, however, social state $y$ is different: The resource can be used to further the education of two, three and four intelligent children, respectively.

- Situation 2: First, Situation 2 (henceforth S2) requires a resource allocation decision between financing an aid program against hunger in Sub-Saharan Africa (social state $^{X}$ ) or financing an environmental program would aim at improving the current situation in the coastal area of the home country (social state $y$ ). In the second, third and fourth steps, social state $x$ is the same, however, social state $y$ is different: The resource can be used to finance some additional environmental

21 There is no doubt some critics of empirical research point out that questionnaires and standardized schedules do suffer from numerous problems. However, they are not shown here because of the scope of the research and the lack of space.

22 Loewenstein (1999: F26) defines external validity as follow: "External validity refers to the ability to generalize from the research context to the settings that the research is intended to approximate".

23 This problem is a kind of resource allocation problem in which there is no possibility of splitting up the funds available.

24 The full original questionnaire (in English), used by Gaertner, can be downloaded from <http://www.vwl-theorie.uniosnabrueck.de/Basic.pdf>. The questionnaire used in this study is an adapted Turkish version of the original one, which is modified to take into account home country situations. In order to check the translation, the Turkish questionnaire was translated back into English by two experienced translators. These two back-translated English versions proved nearly identical. 
programs in the home country. By this way, an additional group of people would benefit from the environmental programs in each step.

- Situation 3: First, Situation 3 (henceforth S3) requires a resource allocation decision between purchasing on the world market badly needed dialysis machines (social state $\boldsymbol{X}$ ) or purchasing on the world market vitamin pills and tropical fruit to upgrade diets of expectant mothers (social state $y$ ). In the second, third and fourth steps, social state $x$ is the same, however, social state $y$ is different: The resource can be used to purchase greater amounts of vitamin pills and tropical fruit. By this way, an additional group of people could also be provided with vitamin pills and tropical fruit in each step.

- Situation 4: First, Situation 4 (henceforth S4) requires a resource allocation decision between purchasing on the world market badly needed dialysis machines (social state $^{x}$ ) or purchasing on the world market Bordeaux wines (social state $y$ ). In the second, third and fourth steps, social state ${ }^{X}$ is the same, however, social state $y$ is different: The resource can be used to import larger quantity of Bordeaux wines. By this way, an additional group of people within society would be able to purchase Bordeaux wines in each step.

- Situation 5: First, Situation 5 (henceforth S5) requires a resource allocation decision between purchasing on the world market inexpensive clothing (social state $\boldsymbol{x}$ ) or purchasing on the world market Bordeaux wines (social state $y$ ). In the second, third and fourth steps, social state $x$ is the same, however, social state $y$ is different: The resource can be used to import larger quantity of Bordeaux wines. By this way, an additional group of people within society would be able to purchase Bordeaux wines in each step.

- Situation 6: First, Situation 6 (henceforth S6) requires a decision between fully restoring workers' rights and "pulling itself up by its bootstraps" (social state ${ }^{X}$ ) or taking up a favorable bank loan at the expense of some basic rights (social state $y$ ). In the second, third and fourth steps, social state $x$ is the same, however, social state $y$ is different: A larger bank loan would be available for the country. By this way, an additional group of the population would benefit from the financial aid in each step. 
Table: 1

Characteristics of Situations

\begin{tabular}{|c|c|c|c|}
\hline Situation & Fund & Social State $x$ & Social State $y$ \\
\hline 1 & Unspecified amount & 1 disabled individual trained to master basic tasks & $\begin{array}{l}\text { Improved language and science skills of } \\
1 \text { gifted child } \\
2 \text { gifted child } \\
3 \text { gifted child } \\
4 \text { gifted child }\end{array}$ \\
\hline 2 & Central bank profit & Food aid to Sub-Saharan Africa & $\begin{array}{l}\text { Environmental projects to } \\
\text { improve ecological conditions in } \\
\text { the coastal area } \\
\text { and reduce air pollution of coal- } \\
\text { fired power plants } \\
\text { and clean up the rivers } \\
\text { and reduce noise along highways }\end{array}$ \\
\hline 3 & Exchange reserve & Purchase dialysis equipment & $\begin{array}{l}\text { Purchase vitamins and fruit to upgrade } \\
\text { diets of } \\
\text { pregnant women } \\
\text { and infants } \\
\text { and teenagers } \\
\text { and workers doing hard physical } \\
\text { labor }\end{array}$ \\
\hline 4 & Exchange reserve & Purchase dialysis equipment & $\begin{array}{l}\text { Import of wine affordable for } \\
\text { well-off citizens } \\
\text { and less well-to-do citizens } \\
\text { and even less prosperous } \\
\text { and even less prosperous }\end{array}$ \\
\hline 5 & Exchange reserve & Import cheap textiles to benefit the needy & $\begin{array}{l}\text { Import of wine affordable for } \\
\text { well-off citizens } \\
\text { and less well-to-do citizens } \\
\text { and even less prosperous } \\
\text { and even less prosperous }\end{array}$ \\
\hline 6 & $\begin{array}{l}\text { Conditional } \\
\text { reconstruction loan }\end{array}$ & $\begin{array}{l}\text { Grant right to strike and freedom of occupational } \\
\text { choice to benefit the country's workers }\end{array}$ & $\begin{array}{l}\text { Eliminate right to strike and freedom of } \\
\text { occupational choice to benefit } \\
\text { employees of large enterprises } \\
\text { and self-employed with small or } \\
\text { medium-sized business } \\
\text { and civil servants } \\
\text { and retired persons }\end{array}$ \\
\hline
\end{tabular}

Source: Jungeilges and Theisen (2008: 1095)

In S1, S2, S3 and S6, both social state ${ }^{\mathcal{X}}$ and social state $\mathcal{y}$ might bring a social benefit that appears to represent a different dimension of needs or dilemmas. However, S4 and S5 are used to analyze the differences in respondents' behavior for various situations. For this purpose, both S4 and S5 in which one might reasonably expect a social benefit from social state $\boldsymbol{X}$, are designed with an alternative state $y$ that establishes a preference which couldn't be perceived as a social pursuit (Jungeilges and Theisen 2011). 
In the framework of the first five situations, alternative social states in respect to the different aspects of needs are derived. However, unlike the others, a dilemma (described as "human rights vs. economic benefits" by Gaertner) is introduced into the framework of S6. Nevertheless, it is still plausible to suppose that the basic decision making problem remains the same in S6. Because, the Rawlsian "difference principle" measures benefit levels by an index of primary social goods that includes rights and liberties, power and opportunity, income and wealth, and the social bases of selfrespect $^{25}$.

In all of the situations just described, the researcher who is attempting to make inference about the context and the compatibility of the experimental setup with Rawlsian approach is faced with a difficult task. To overcome this difficulty, one may basically perceive the experimental design/the problem/the context of situations as a dynamic structure which differs depending on the features of the sample being studied. For example, in my study, the respondents have placed themselves in some other person's shoes rather than having been an outside judge, only for the scenario used in S2 (according to the written comments of the respondents). In other words, the respondents have behaved as external judges/impartial spectators in the rest of the situations ${ }^{26}$. Furthermore, the impartiality of the respondent is not necessarily needed for this analysis as well. Because "In a Rawlsian setup, it is an outside observer who evaluates all the persons under all states or all persons involved agree unanimously on the same interpersonal ordering; the latter process is due to the Rawlsian 'veil of ignorance' "(Gaertner and Jungeilges 2002: 34) 27. $^{27}$

\section{Data Collection and Features of the Sample}

In order to investigate whether the pattern differences in approach to Rawlsian justice are associated with economics training, I used the above-mentioned survey -in which six situations were considered- designed by Gaertner. The purpose of this choice is explained in the previous section.

Certainly, both questionnaire methods and pure experimental techniques can be employed to assess respondents' perceptions of justice. Experimental inquiries with financial incentives and survey studies each shed light on different aspects of the empirical research. However, both methods have advantages and disadvantages that need to be discussed ${ }^{28}$. Although the lack of a financial incentive may be regarded as a problem from a traditional perspective (Hey and Pasca $2011)^{29}$, the research design adopted for this study is the survey method using a questionnaire to collect data. This is because in order to reach unbiased views, it might be better to prefer a technique, which cannot be manipulated through monetary stakes, for the sake of investigating the genuine methodological issues associated with justice and equity (Faravelli 2007; Gaertner and Schokkaert 2011). "Unlike branches of experimental economics where the focus is on individual actions leading

25 For a more detailed explanation, see Gaertner and Schwettmann (2007).

26 However, this may not be the case for other studies using different samples. For further arguments and examples, see Gaertner and Jungeilges (2002); Gaertner and Schwettmann (2007); and Jungeilges and Theisen (2008).

27 For a discussion of the relationship between VOI, impartiality and inequality aversion/risk aversion, see Amiel et al. (2009); Bosmans and Schokkaert (2004); Carlsson et al. (2005); and Carlsson et al. (2003).

28 For more information, see Konow (2003).

29 However, at the same time, the use of monetary incentives is subject to both internal and external validity criticism. 
to personal gain, it is not clear that rewards to participants are necessary in the context of social judgments" (Cowell and Schokkaert 2001: 942) ${ }^{30}$. An advantage of the survey method, in particular, is that it exhibits low self-interest bias (Konow 2003), especially if the aim is to derive information about norms (Gaertner and Schokkaert 2011). Therefore, the questionnaire technique has recently become more and more used in the economics literature for exploring distributive justice (Bosmans and Schokkaert 2004).

The survey was carried out during the first three months of 2012. The questionnaire was applied to a sample of 80 first-year, 55 second-year, 69 third-year, 37 final-year and 50 graduate students of the Department of Public Finance at Hacettepe University. The information of the sample is given in Table 2 .

Table: 2

Characteristics of the Sample

\begin{tabular}{|c|c|c|c|c|c|}
\hline & $1^{\text {st }}$ & $2^{\text {nd }}$ & $3^{\text {rd }}$ & $4^{\text {th }}$ & Grad. \\
\hline Number of students & 80 & 55 & 69 & 37 & 50 \\
\hline & 20.8 & 21.3 & 22.7 & 23 & 30.1 \\
\hline Mean age or students & $(1.51)$ & $(1.05)$ & $(1.95)$ & $(1.69)$ & $(6.07)$ \\
\hline$\%$ male students & 57.50 & 47.27 & 63.77 & 40.54 & 74.00 \\
\hline$\%$ students who have work experience & 58.75 & 52.73 & 55.07 & 37.84 & 78.00 \\
\hline
\end{tabular}

Notes: Standard deviations are reported in parentheses.

The questionnaire, with some additional questions relating to demographic characteristics, income distribution and parental background, was administered, to the students through the assistance of some colleagues, during lecture hours or just before taking a test ${ }^{31,32}$. Communication between respondents was strictly prohibited. The participants were seated separately in classroom-size groups (generally, 25-30 students) to ensure confidentiality of answers. The mean age of the whole sample was 23.2 years $^{33}$, with a range from 18 years to 47 years and it comprised $42.27 \%$ women and $57.73 \%$ men. In addition, $57.39 \%$ of students have work experience.

Since this study is an attempt to investigate whether there is an indoctrination effect of economics training on the perception of distributive justice, the primary focus therefore is on courses taken by students at different stages of their university study. Moreover, the information on the number of years studied allows us to address the issue whether students become more egalitarian, in a Rawlsian sense, as they become more familiar with welfare economics or vice versa. Table 3 provides a list of the relevant courses offered by the Department of Public Finance at Hacettepe University. It is clearly seen in the Table 3 that the number of courses related to welfare economics and theories of justice increases as students' progress with their studies.

30 For further discussion, see Gneezy and Rustichini (2000); Guala (2005); Read (2005); and Vieider (2011).

31 The students were informed that the questionnaire was anonymous, and no individual student's answers could be identified. They were assured that no right or wrong answer existed, and they were not expected to answer in any particular fashion. In addition, the students were discussed that the questionnaire -just seeking their opinion-would not be used for any other purpose.

32 The original questionnaire also contains the additional questions asked by Gaertner.

33 The standard deviation of the mean age was approximately 4.34 years. 
Table: 3

The List of the Welfare-Related Courses

\begin{tabular}{cl}
\hline Stage of Economics Education & \multicolumn{1}{c}{ Courses related to welfare economics and theories of justice } \\
\hline $1^{\text {st }}$ year & Introduction to Economics I (C), Introduction to Economics II (C) \\
$2^{\text {nd }}$ year & Introduction to Public Finance (C), Theory of Public Finance (C), Microeconomic Theory I (C), \\
$3^{\text {rd }}$ year & Microeconomic Theory II (C) \\
$4^{\text {th }}$ year & Public Economics I (C), Public Economics II (C), History of Economic and Fiscal Thoughts (C) \\
& Economic Development and Growth (C), Fiscal Policy (C), Economics of Taxation (E) \\
& Microeconomic Analysis (C), Public Choice Theory (E), The Principles and Policies of \\
Graduate & Taxation (E), Fiscal Policy Analysis (E), The History of Economics and Fiscal Thoughts (E), \\
& Microeconomic Applications (C), The Policies of Taxation (E), New Issues in the Theory of \\
& Public Finance (E) \\
\hline Notes: The information in parentheses following each course is as follows: C for compulsory courses, E for elective courses.
\end{tabular}

\section{Descriptive Data Analysis}

Since I seek to identify possible behavioral difference among students in different years of the curriculum, the results that indicate the relative frequencies for all possible decision patterns in each situation will be presented in Table 4.1 and 4.2. However, first a brief explanation will be made on the coding system that has been developed to identify and evaluate the decision sequence of the respondents.

A sequence of four decisions determines the response pattern of each student on alternative states for each situation. The respondent faces a simple decision making problem, in a dichotomous choice situation, on whether to make a Rawlsian decision between alternative allocations. ${ }^{0}$ represents a choice of social state $x$, while the alternative social state $y$ is recorded as . A dichotomous sequence of a series of decisions consisting of four digits represents a student's preferences in the base situation and all its variants.

The first and second columns of Table 4.1 and 4.2 contain the set of possible choices under any of the decision situations and their representations (henceforth $R$ ), respectively. The main patterns of decision making behavior can be classified into three categories: (i) Strictly Rawlsian $(R: 0)$, (ii) Non-Rawlsian $(R: 15)$, and (iii) Others (The rest of the cases).

In addition, it is possible to suggest some alternative indicators for a better comparison between samples. For this purpose, the lower part of the Table 4.1 and 4.2 includes two additional values: (i) Switch (revisions of the original decision in support of worst-off/ $(R: 1,3,7)$, and (ii) Fulfillment of the "equity axiom" (all cases beginning with $0 /(R: 0,1,2,3,4,5,6,7)$ ).

However, it is very difficult to evaluate and interpret two groups of decision sequences. The first group includes the decision patterns which indicate switches back and forth between deciding in support of worst-off $(R: 2,4,5,6,9,10,11,13)$, and the second group reflects the decisions of the individuals that adhere to the "equity axiom" at a later stage of the decision making process $(R: 8,12,14)$. 
Table: 4.1

Relative Frequencies (S1, S2, S3)

\begin{tabular}{|c|c|c|c|c|c|c|c|c|c|c|c|c|c|c|c|c|}
\hline \multirow{2}{*}{ Cases } & \multirow{2}{*}{$\begin{array}{l}\text { Dec. } \\
\text { Rep. }^{\text {a }}\end{array}$} & \multicolumn{5}{|c|}{ Situation 1} & \multicolumn{5}{|c|}{ Situation 2} & \multicolumn{5}{|c|}{ Situation 3} \\
\hline & & $1^{\text {st }}$ & $2^{\text {nd }}$ & $3^{\text {rd }}$ & $4^{\text {th }}$ & Gra $^{b}$ & $1^{\text {st }}$ & $2^{\text {nd }}$ & $3^{\text {rd }}$ & $4^{\text {th }}$ & Gra & $1^{\text {st }}$ & $2^{\text {nd }}$ & $3^{\text {rd }}$ & $4^{\text {th }}$ & Gra \\
\hline 0000 & 0 & 0.350 & 0.254 & 0.304 & 0.297 & 0.440 & 0.512 & 0.382 & 0.478 & 0.432 & 0.380 & 0.425 & 0.472 & 0.304 & 0.405 & 0.440 \\
\hline 0001 & 1 & 0.000 & 0.054 & 0.043 & 0.000 & 0.020 & 0.012 & 0.000 & 0.029 & 0.000 & 0.020 & 0.062 & 0.000 & 0.043 & 0.000 & 0.040 \\
\hline 0010 & 2 & 0.012 & 0.000 & 0.000 & 0.000 & 0.000 & 0.037 & 0.091 & 0.014 & 0.000 & 0.040 & 0.000 & 0.000 & 0.000 & 0.000 & 0.020 \\
\hline 0011 & 3 & 0.075 & 0.091 & 0.087 & 0.135 & 0.040 & 0.100 & 0.054 & 0.087 & 0.027 & 0.020 & 0.075 & 0.091 & 0.145 & 0.027 & 0.040 \\
\hline 0100 & 4 & 0.025 & 0.000 & 0.000 & 0.000 & 0.000 & 0.000 & 0.018 & 0.000 & 0.000 & 0.000 & 0.000 & 0.000 & 0.014 & 0.000 & 0.020 \\
\hline 0101 & 5 & 0.012 & 0.000 & 0.014 & 0.000 & 0.020 & 0.000 & 0.018 & 0.000 & 0.000 & 0.000 & 0.000 & 0.000 & 0.000 & 0.000 & 0.000 \\
\hline 0110 & 6 & 0.037 & 0.018 & 0.014 & 0.027 & 0.060 & 0.025 & 0.036 & 0.029 & 0.000 & 0.020 & 0.000 & 0.000 & 0.014 & 0.000 & 0.020 \\
\hline 0111 & 7 & 0.287 & 0.127 & 0.275 & 0.270 & 0.160 & 0.037 & 0.036 & 0.058 & 0.081 & 0.060 & 0.175 & 0.054 & 0.159 & 0.162 & 0.180 \\
\hline 1000 & 8 & 0.000 & 0.000 & 0.000 & 0.000 & 0.060 & 0.012 & 0.000 & 0.014 & 0.000 & 0.020 & 0.012 & 0.000 & 0.000 & 0.000 & 0.000 \\
\hline 1001 & 9 & 0.012 & 0.000 & 0.000 & 0.000 & 0.000 & 0.000 & 0.000 & 0.000 & 0.000 & 0.000 & 0.000 & 0.018 & 0.000 & 0.000 & 0.020 \\
\hline 1010 & 10 & 0.000 & 0.036 & 0.029 & 0.000 & 0.000 & 0.012 & 0.018 & 0.043 & 0.000 & 0.020 & 0.000 & 0.000 & 0.014 & 0.000 & 0.000 \\
\hline 1011 & 11 & 0.000 & 0.000 & 0.000 & 0.027 & 0.000 & 0.025 & 0.000 & 0.000 & 0.027 & 0.020 & 0.012 & 0.000 & 0.000 & 0.027 & 0.000 \\
\hline 1100 & 12 & 0.025 & 0.018 & 0.000 & 0.000 & 0.020 & 0.025 & 0.018 & 0.000 & 0.027 & 0.020 & 0.025 & 0.054 & 0.029 & 0.000 & 0.040 \\
\hline 1101 & 13 & 0.000 & 0.018 & 0.000 & 0.000 & 0.000 & 0.000 & 0.000 & 0.000 & 0.000 & 0.000 & 0.000 & 0.000 & 0.000 & 0.000 & 0.000 \\
\hline 1110 & 14 & 0.025 & 0.018 & 0.029 & 0.000 & 0.000 & 0.050 & 0.018 & 0.043 & 0.081 & 0.040 & 0.012 & 0.000 & 0.043 & 0.027 & 0.020 \\
\hline 1111 & 15 & 0.137 & 0.364 & 0.203 & 0.243 & 0.180 & 0.150 & 0.309 & 0.203 & 0.324 & 0.340 & 0.200 & 0.309 & 0.232 & 0.351 & 0.160 \\
\hline \multicolumn{2}{|l|}{$\%$ Switch } & 36.3 & 27.3 & 40.6 & 40.5 & 22.0 & 15.0 & 9.1 & 17.4 & 10.8 & 10.0 & 31.3 & 14.5 & 34.8 & 18.9 & 26.0 \\
\hline \multicolumn{2}{|c|}{$\%$ Fulfillment ${ }^{\mathrm{c}}$} & 80.0 & 54.5 & 73.9 & 73.0 & 74.0 & 72.5 & 63.6 & 69.6 & 54.1 & 54.0 & 73.8 & 61.8 & 68.1 & 59.5 & 76.0 \\
\hline
\end{tabular}

Notes: ${ }^{a}$ Decimal Representation, ${ }^{b}$ Graduate, ${ }^{c}$ Fulfillment of "equity axiom". 
Table: 4.2

Relative Frequencies (S4, S5, S6)

\begin{tabular}{|c|c|c|c|c|c|c|c|c|c|c|c|c|c|c|c|c|}
\hline \multirow{2}{*}{ Cases } & \multirow{2}{*}{$\begin{array}{l}\text { Dec. } \\
\text { Rep. }^{\text {a }}\end{array}$} & \multicolumn{5}{|c|}{ Situation 4} & \multicolumn{5}{|c|}{ Situation 5} & \multicolumn{5}{|c|}{ Situation 6} \\
\hline & & $1^{\text {st }}$ & $2^{\text {nd }}$ & $3^{\text {rd }}$ & $4^{\text {th }}$ & Gra $^{b}$ & $1^{\text {st }}$ & $2^{\text {nd }}$ & $3^{\text {rd }}$ & $4^{\text {th }}$ & Gra & $1^{\text {st }}$ & $2^{\text {nd }}$ & $3^{\text {rd }}$ & $4^{\text {th }}$ & Gra \\
\hline 0000 & 0 & 0.862 & 0.909 & 0.884 & 0.946 & 0.880 & 0.712 & 0.836 & 0.841 & 0.811 & 0.860 & 0.387 & 0.564 & 0.362 & 0.459 & 0.420 \\
\hline 0001 & 1 & 0.050 & 0.000 & 0.029 & 0.000 & 0.060 & 0.087 & 0.018 & 0.029 & 0.054 & 0.080 & 0.100 & 0.018 & 0.087 & 0.054 & 0.100 \\
\hline 0010 & 2 & 0.000 & 0.000 & 0.000 & 0.000 & 0.000 & 0.000 & 0.000 & 0.000 & 0.000 & 0.000 & 0.000 & 0.000 & 0.000 & 0.000 & 0.000 \\
\hline 0011 & 3 & 0.025 & 0.054 & 0.029 & 0.000 & 0.020 & 0.025 & 0.036 & 0.000 & 0.027 & 0.000 & 0.062 & 0.091 & 0.043 & 0.054 & 0.100 \\
\hline 0100 & 4 & 0.012 & 0.000 & 0.014 & 0.027 & 0.000 & 0.012 & 0.000 & 0.014 & 0.000 & 0.000 & 0.012 & 0.000 & 0.000 & 0.000 & 0.000 \\
\hline 0101 & 5 & 0.000 & 0.000 & 0.000 & 0.000 & 0.000 & 0.000 & 0.000 & 0.000 & 0.000 & 0.000 & 0.000 & 0.000 & 0.000 & 0.000 & 0.000 \\
\hline 0110 & 6 & 0.000 & 0.018 & 0.014 & 0.000 & 0.000 & 0.012 & 0.000 & 0.000 & 0.000 & 0.000 & 0.012 & 0.000 & 0.000 & 0.000 & 0.000 \\
\hline 0111 & 7 & 0.012 & 0.000 & 0.000 & 0.027 & 0.000 & 0.075 & 0.054 & 0.058 & 0.108 & 0.020 & 0.100 & 0.036 & 0.072 & 0.108 & 0.060 \\
\hline 1000 & 8 & 0.000 & 0.000 & 0.000 & 0.000 & 0.000 & 0.012 & 0.000 & 0.000 & 0.000 & 0.000 & 0.000 & 0.000 & 0.000 & 0.000 & 0.020 \\
\hline 1001 & 9 & 0.000 & 0.000 & 0.000 & 0.000 & 0.000 & 0.000 & 0.000 & 0.000 & 0.000 & 0.000 & 0.000 & 0.000 & 0.000 & 0.000 & 0.000 \\
\hline 1010 & 10 & 0.000 & 0.000 & 0.000 & 0.000 & 0.000 & 0.000 & 0.018 & 0.000 & 0.000 & 0.000 & 0.000 & 0.000 & 0.014 & 0.000 & 0.000 \\
\hline 1011 & 11 & 0.000 & 0.000 & 0.000 & 0.000 & 0.020 & 0.000 & 0.000 & 0.000 & 0.000 & 0.000 & 0.000 & 0.000 & 0.000 & 0.000 & 0.020 \\
\hline 1100 & 12 & 0.025 & 0.000 & 0.000 & 0.000 & 0.000 & 0.025 & 0.000 & 0.000 & 0.000 & 0.000 & 0.000 & 0.036 & 0.000 & 0.000 & 0.000 \\
\hline 1101 & 13 & 0.000 & 0.000 & 0.000 & 0.000 & 0.000 & 0.012 & 0.000 & 0.000 & 0.000 & 0.000 & 0.000 & 0.000 & 0.029 & 0.000 & 0.000 \\
\hline 1110 & 14 & 0.000 & 0.000 & 0.000 & 0.000 & 0.000 & 0.000 & 0.000 & 0.029 & 0.000 & 0.000 & 0.012 & 0.000 & 0.029 & 0.027 & 0.000 \\
\hline 1111 & 15 & 0.012 & 0.018 & 0.029 & 0.000 & 0.020 & 0.025 & 0.036 & 0.029 & 0.000 & 0.040 & 0.312 & 0.254 & 0.362 & 0.297 & 0.280 \\
\hline \multicolumn{2}{|c|}{$\%$ Switch } & 8.8 & 5.5 & 5.8 & 2.7 & 8.0 & 18.8 & 10.9 & 8.7 & 18.9 & 10.0 & 26.3 & 14.5 & 20.3 & 21.6 & 26.0 \\
\hline \multicolumn{2}{|c|}{$\%$ Fulfillment ${ }^{\mathrm{c}}$} & 96.3 & 98.2 & 97.1 & 100 & 96.0 & 92.5 & 94.5 & 94.2 & 100 & 96.0 & 67.5 & 70.9 & 56.5 & 67.6 & 68.0 \\
\hline
\end{tabular}

Notes: ${ }^{a}$ Decimal Representation, ${ }^{b}$ Graduate, ${ }^{c}$ Fulfillment of "equity axiom". 


\section{Situation 1}

The preferences for the fulfillment of "equity axiom" diminish from the freshmen (80\%) to the sophomores $(54.5 \%)$. However, the percentage of preferences for the fulfillment of "equity axiom" is almost identical in the other groups (73.9\% for the juniors, $73 \%$ for the seniors, and $74 \%$ for the graduate students). Furthermore, interestingly, only the graduate students have a low tendency to revise their original decision (22\%). Switching is considerably higher among both the juniors and the seniors ( $40.6 \%$ and $40.5 \%$, respectively) when compared with the graduate students. The highest relative frequency of unconditional support for the worst-off individual is found in the group of the graduate students (44\%). In addition, $36.4 \%$ of the sophomores want the resource to go towards the education of the intelligent child(ren) unconditionally. As an interesting point, it may be noted that the variety of the choices made grows among the freshmen.

\section{Situation 2}

The propensity to decide in accordance with Rawlsian principles is highest among the first-year students. The decision to give the money (unconditionally) to the starving people in SubSaharan Africa is strong $(51.2 \%, 38.2 \%, 47.8 \%, 43.2 \%, 38 \%)^{34}$; and this is also the case for the decision in favor of supporting the environmental program $(15 \%, 30.9 \%, 20.3 \%, 32.4 \%, 34 \%)$. Moreover, all groups demonstrate a low switch frequency $(15 \%, 9.1 \%, 17.4 \%, 10.8 \%, 10 \%)$.

\section{Situation 3}

The percentages of the students with an intention to purchase dialysis machines unconditionally are close to each other, regardless of which group they belong to $(42.5 \%, 47.2 \%$, $30.4 \%, 40.5 \%, 44 \%)$. However, the frequencies of switching are a little different between cohorts $(31.3 \%, 14.5 \%, 34.8 \%, 18.9 \%, 26 \%)$. The highest frequency of fulfillment of the "equity axiom", $76 \%$, is observed in the graduate students. The percentages of the respondents satisfying the "equity axiom" are relatively high for the first and third-year students, $73.8 \%$ and $68.1 \%$, respectively (compared with the second and fourth-year students, $61.8 \%$ and $59.5 \%$, respectively).

\section{Situation 4}

The violation of the "equity axiom" is almost negligible. The propensity to decide in accordance with Rawlsian principles is very high for all groups $(96.3 \%, 98.2 \%, 97.1 \%, 100 \%, 96 \%)$. Switches occur much more often in the first and last groups, $8.8 \%$ and $8 \%$, respectively.

\section{Situation 5}

Although the frequency of fulfillment of "equity axiom" in first three groups is slightly less than that observed in S4, the values are exactly the same for the rest of the groups $(92.5 \%$, $94.5 \%, 94.2 \%, 100 \%, 96 \%)$. The violation of the "equity axiom" is almost negligible as well. The average switching frequency of the respondents is about $13.5 \%$. Only the seniors show a percentage lower than $10 \%(18.8 \%, 10.9 \%, 8.7 \%, 18.9 \%, 10 \%)$.

\footnotetext{
34 The first percentage always refers to the freshmen, the second one to the sophomores, the third one to the juniors, the fourth one to the seniors, and the last one to the graduate students.
} 
Seniority: A Blessing or A Curse? The Effect of Economics

Training on the Perception of Distributive Justice

Table: 5

Chi-Square Tests for Two Independent Samples

\begin{tabular}{|c|c|c|c|c|}
\hline Stage & $2^{\text {nd }}$ year & $3^{\text {rd }}$ year & $4^{\text {th }}$ year & Graduate \\
\hline \multicolumn{5}{|c|}{ Situation 1} \\
\hline $1^{\text {st }}$ year & $\begin{array}{c}24.79^{* * *} \\
(13)\end{array}$ & $\begin{array}{r}13.00 \\
(12)\end{array}$ & $\begin{array}{r}9.27 \\
(11)\end{array}$ & $\begin{array}{r}14.35 \\
(12)\end{array}$ \\
\hline $2^{\text {nd }}$ year & & $\begin{array}{c}9.97 \\
(10)\end{array}$ & $\begin{array}{r}10.96 \\
(10)\end{array}$ & $\begin{array}{r}17.10 \\
(11)\end{array}$ \\
\hline $3^{\text {rd }}$ year & & & $\begin{array}{r}7.08 \\
(9)\end{array}$ & $\begin{array}{r}14.93 \\
(10)\end{array}$ \\
\hline $4^{\text {th }}$ year & & & & $\begin{array}{r}11.49 \\
(9) \\
\end{array}$ \\
\hline \multicolumn{5}{|c|}{ Situation 2} \\
\hline $1^{\text {st }}$ year & $\begin{array}{r}14.28 \\
(13)\end{array}$ & $\begin{array}{r}7.15 \\
11\end{array}$ & $\begin{array}{r}10.89 \\
(11)\end{array}$ & $\begin{array}{r}9.84 \\
(11)\end{array}$ \\
\hline $2^{\text {nd }}$ year & & $\begin{array}{r}13.87 \\
(12)\end{array}$ & $\begin{array}{r}11.66 \\
(11)\end{array}$ & $\begin{array}{r}8.03 \\
(13)\end{array}$ \\
\hline $3^{\text {rd }}$ year & & & $\begin{array}{r}12.22 \\
(11)\end{array}$ & $\begin{array}{r}9.17 \\
(11)\end{array}$ \\
\hline $4^{\text {th }}$ year & & & & $\begin{array}{r}5.50 \\
(11) \\
\end{array}$ \\
\hline \multicolumn{5}{|c|}{ Situation 3} \\
\hline $1^{\text {st }}$ year & $\begin{array}{r}13.33 \\
(9)\end{array}$ & $\begin{array}{r}10.18 \\
(11)\end{array}$ & $\begin{array}{r}7.68 \\
(8)\end{array}$ & $\begin{array}{c}9.18 \\
(12)\end{array}$ \\
\hline $2^{\text {nd }}$ year & & $\begin{array}{r}15.62 \\
(10)\end{array}$ & $\begin{array}{r}10.01 \\
\text { (7) }\end{array}$ & $\begin{array}{r}13.85 \\
(10)\end{array}$ \\
\hline $3^{\text {rd }}$ year & & & $\begin{array}{r}11.53 \\
(10)\end{array}$ & $\begin{array}{r}9.64 \\
(11)\end{array}$ \\
\hline $4^{\text {th }}$ year & & & & $\begin{array}{r}10.75 \\
(11) \\
\end{array}$ \\
\hline \multicolumn{5}{|c|}{ Situation 4} \\
\hline $1^{\text {st }}$ year & $\begin{array}{r}7.87 \\
(7)\end{array}$ & $\begin{array}{r}4.71 \\
(7)\end{array}$ & $\begin{array}{r}4.99 \\
(6)\end{array}$ & $\begin{array}{l}4.31 \\
(7)\end{array}$ \\
\hline $2^{\text {nd }}$ year & & $\begin{array}{r}3.08 \\
(5)\end{array}$ & $\begin{array}{r}6.37 \\
(5)\end{array}$ & $\begin{array}{r}6.16 \\
(5)\end{array}$ \\
\hline $3^{\text {rd }}$ year & & & $\begin{array}{r}5.92 \\
(6)\end{array}$ & $\begin{array}{r}3.68 \\
(6)\end{array}$ \\
\hline $4^{\text {th }}$ year & & & & $\begin{array}{r}7.24 \\
(6) \\
\end{array}$ \\
\hline \multicolumn{5}{|c|}{ Situation 5} \\
\hline $1^{\text {st }}$ year & $\begin{array}{c}9.37 \\
(10)\end{array}$ & $\begin{array}{r}11.44 \\
(10)\end{array}$ & $\begin{array}{r}4.73 \\
(9)\end{array}$ & $\begin{array}{r}7.84 \\
(9)\end{array}$ \\
\hline $2^{\text {nd }}$ year & & $\begin{array}{r}6.36 \\
(7)\end{array}$ & $\begin{array}{r}3.80 \\
(5)\end{array}$ & $\begin{array}{r}5.68 \\
(5)\end{array}$ \\
\hline $3^{\text {rd }}$ year & & & $\begin{array}{r}5.77 \\
(6)\end{array}$ & $\begin{array}{r}4.78 \\
(5)\end{array}$ \\
\hline $4^{\text {th }}$ year & & & & $\begin{array}{r}5.97 \\
(4) \\
\end{array}$ \\
\hline & & Situation & & \\
\hline $1^{\text {st }}$ year & $\begin{array}{r}12.96 \\
(8)\end{array}$ & $\begin{array}{r}6.68 \\
(9)\end{array}$ & $\begin{array}{r}2.25 \\
(7)\end{array}$ & $\begin{array}{r}6.41 \\
(9)\end{array}$ \\
\hline $2^{\text {nd }}$ year & & $\begin{array}{r}14.71^{*} \\
(8)\end{array}$ & $\begin{array}{r}6.45 \\
(6)\end{array}$ & $\begin{array}{r}8.57 \\
(7)\end{array}$ \\
\hline $3^{\text {rd }}$ year & & & $\begin{array}{r}3.25 \\
(7)\end{array}$ & $\begin{array}{r}8.73 \\
(9)\end{array}$ \\
\hline $4^{\text {th }}$ year & & & & $\begin{array}{r}4.66 \\
(7) \\
\end{array}$ \\
\hline
\end{tabular}

Notes: Level of significance: $* 10 \%, * * 5 \%$. Degrees of freedom are reported in parentheses. 


\section{Situation 6}

The frequency of the sequence is lowest among the juniors and highest among the sophomores $(38.7 \%, 56.4 \%, 36.2 \%, 45.9 \%, 42 \%)$. The fulfillment of the "equity axiom" is very similar for all groups except the juniors $(67.5 \%, 70.9 \%, 56.5 \%, 67.6 \%, 68 \%)$. In addition, the percentages of respondents revise their decisions are $26.3 \%, 14.5 \%, 20.3 \%, 21.6 \%$, and $26 \%$. Interestingly, the frequencies for Case 0 (sequence) and Case 15 (sequence) ${ }^{35}$ are identical, $36.2 \%$, among the third-year students.

Despite the fact that the descriptive data used so far provide the raw material for assessing the relation between decision makers' preferences and the level of economics knowledge, I should like to carry this analysis a little further by applying chi-square tests. The hypothesis that will be tested is the following:

HO: There is no relation between the preference of a decision choice and the class level.

Table 5 shows the results of the hypothesis testing. The test statistic is calculated at each of the six situations ${ }^{36}$. There are just two statistically significant differences between the groups with regard to the distribution of the choices among the sixty comparisons. The first one is between the freshmen and the sophomores in S1, and the second one is between the sophomores and the juniors in S6. However, the risk of misinterpretation makes me hesitant to rely on these results without considering the homogeneity of the sample population under study ${ }^{37}$. Therefore, I would defer drawing conclusions from these findings until a regression with coefficients that reflect the sociodemographic features of the sample is produced. In the next section I will perform a standard probit regression that can provide the necessary information for the interpretation step.

\section{Regression Analysis}

Three decision patterns mentioned earlier (Fulfillment of the "equity axiom", Switch, and Strictly Rawlsian) are used as dichotomous dependent variables in the probit analyses. The independent variables can be grouped into two categories. The first category contains information on the personal factors and socio-demographic position of the respondents (age, job experience, gender, future income expectation, and parental background), and the second category includes dummy variables for the year in university (The term "Class Level Variables" -henceforth CLV- will be used to express the group of the second category variables). The explanatory variables are described in Table 6.

36 The results for the sixty chi-square tests are given in Table 5.

37 Undoubtedly, the absence of statistically significant results may be caused by a number of factors such as sample size, overrepresentation, noisy data, etc., as well as homogeneity. 
Table: 6

Labels and Descriptions of the Explanatory Variables

\begin{tabular}{|c|c|c|c|}
\hline Label & Description & Mean $^{a}$ & S.D. \\
\hline Age & Age of respondent (in years) & 23.23 & 4.34 \\
\hline $\mathrm{Job}$ & Respondent has job experience: $0=$ No, $1=$ Yes & 0.57 & 0.49 \\
\hline Male & Respondent is male: $0=\mathrm{No}, 1=\mathrm{Yes}$ & 0.58 & 0.49 \\
\hline \multicolumn{4}{|c|}{ Future Income ${ }^{b}$} \\
\hline Future 1 & less than $50 \%$ & 0.15 & 0.35 \\
\hline Future 2 & $50 \%$ & 0.47 & 0.50 \\
\hline Future 3 & more than $50 \%$ & 0.38 & 0.49 \\
\hline \multicolumn{4}{|c|}{ Parental Background $^{\mathrm{c}}$} \\
\hline Parents 1 & Worker, craftsman & 0.10 & 0.30 \\
\hline Parents 2 & Employee or civil servant in the public sector & 0.55 & 0.50 \\
\hline Parents 3 & Employee in the private sector & 0.16 & 0.37 \\
\hline Parents 4 & Self-employed & 0.19 & 0.39 \\
\hline \multicolumn{4}{|c|}{ Class Level $^{\mathrm{d}}$} \\
\hline Freshman & First-year student & 0.27 & 0.45 \\
\hline Sophomore & Second-year student & 0.19 & 0.39 \\
\hline Junior & Third- year student & 0.24 & 0.43 \\
\hline Senior & Fourth-year student & 0.13 & 0.33 \\
\hline Graduate & Graduate student & 0.17 & 0.38 \\
\hline
\end{tabular}


Table: 7.1

ML Estimates of Probit Models (S1 and S2)

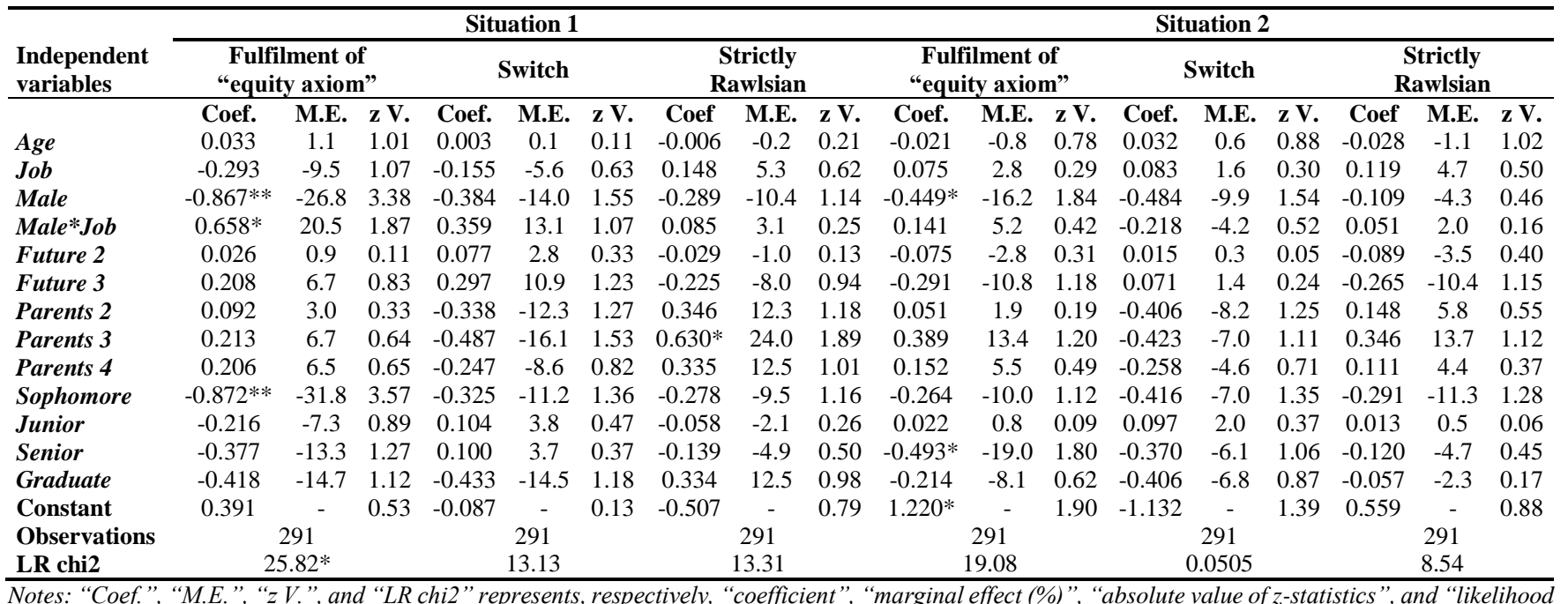

ratio test statistic".

Reference group consists of Female, Future 1, Parents 1, and Freshman.

Level of significance: $* 5 \%$, $* * 1 \%$. 
Table: 7.2

ML Estimates of Probit Models (S3 and S4)

\begin{tabular}{|c|c|c|c|c|c|c|c|c|c|c|c|c|c|c|c|c|c|c|}
\hline \multirow{3}{*}{$\begin{array}{l}\text { Independent } \\
\text { variables }\end{array}$} & \multicolumn{9}{|c|}{ Situation 3} & \multicolumn{9}{|c|}{ Situation 4} \\
\hline & \multicolumn{3}{|c|}{$\begin{array}{l}\text { Fulfilment of } \\
\text { "equity axiom" }\end{array}$} & \multicolumn{3}{|c|}{ Switch } & \multicolumn{3}{|c|}{$\begin{array}{c}\text { Strictly } \\
\text { Rawlsian } \\
\end{array}$} & \multicolumn{3}{|c|}{$\begin{array}{l}\text { Fulfilment of } \\
\text { "equity axiom" }\end{array}$} & \multicolumn{3}{|c|}{ Switch } & \multicolumn{3}{|c|}{$\begin{array}{c}\text { Strictly } \\
\text { Rawlsian }\end{array}$} \\
\hline & Coef. & M.E. & z V. & Coef. & M.E. & $\mathbf{z} \mathbf{V}$. & Coef & M.E. & z V. & Coef. & M.E. & $\mathrm{z} \mathrm{V}$ & Coef. & M.E. & z V. & Coef & M.E. & $\mathrm{z} \mathrm{V}$. \\
\hline$J o b$ & -0.046 & -1.6 & 0.18 & -0.443 & -14.2 & 1.60 & 0.182 & 7.0 & 0.77 & $5.365^{* * *}$ & 11.1 & 12.22 & $-4.921 * *$ & -66.1 & 16.51 & $0.899 *$ & 16.9 & 2.02 \\
\hline Male & -0.130 & -4.5 & 0.52 & 0.174 & 5.4 & 0.71 & -0.285 & -11.1 & 1.17 & 5.319 & 13.0 & - & $0.723^{*}$ & 1.5 & 2.01 & -0.129 & -2.2 & 0.44 \\
\hline Male*Job & -0.316 & -11.2 & 0.92 & -0.116 & -3.6 & 0.32 & -0.076 & -2.9 & 0.23 & -10.432 & -88.9 & - & 4.443 & 59.2 & - & -0.705 & -13.2 & 1.35 \\
\hline Future 2 & 0.049 & 1.7 & 0.21 & 0.375 & 11.9 & 1.48 & -0.239 & -9.2 & 1.05 & -4.884 & -2.9 & 0.00 & -0.239 & -0.5 & 0.64 & 0.144 & 2.4 & 0.48 \\
\hline Parents 2 & 0.103 & 3.6 & 0.38 & -0.359 & -11.4 & 1.30 & 0.388 & 14.8 & 1.40 & -4.794 & -0.2 & 0.00 & 0.065 & 0.1 & 0.16 & -0.381 & -6.3 & 0.98 \\
\hline Parents 3 & -0.126 & -4.5 & 0.40 & -0.539 & -14.7 & 1.62 & 0.302 & 11.9 & 0.95 & - & - & - & -0.491 & -0.8 & 0.82 & -0.186 & -3.4 & 0.41 \\
\hline Parents 4 & -0.255 & -9.3 & 0.83 & -0.403 & -11.5 & 1.26 & 0.113 & 4.4 & 0.36 & -4.968 & -28.0 & 0.00 & 0.073 & 0.2 & 0.15 & -0.313 & -6.0 & 0.72 \\
\hline Sophomore & -0.349 & -12.8 & 1.47 & $-0.620^{*}$ & -16.8 & 2.32 & 0.135 & 5.3 & 0.59 & 0.582 & 0.0 & 1.02 & -0.183 & -0.4 & 0.48 & 0.233 & 3.6 & 0.75 \\
\hline Junior & -0.216 & -7.8 & 0.93 & 0.022 & 0.7 & 0.10 & -0.305 & -11.5 & 1.36 & 0.288 & 0.0 & 0.56 & -0.246 & -0.5 & 0.70 & 0.126 & 2.0 & 0.45 \\
\hline Senior & $-0.552 *$ & -20.8 & 1.99 & $-0.528 *$ & -14.3 & 1.76 & -0.067 & -2.6 & 0.25 & - & - & - & -0.549 & -0.8 & 1.05 & 0.441 & 6.0 & 1.14 \\
\hline Graduate & -0.127 & -4.5 & 0.34 & -0.233 & -7.0 & 0.64 & 0.021 & 0.8 & 0.06 & 0.551 & 0.0 & 0.69 & 0.321 & 0.9 & 0.61 & 0.066 & 1.1 & 0.15 \\
\hline Constant & 0.431 & - & 0.62 & -0.522 & - & 0.78 & -0.188 & - & 0.29 & 11.764 & - & - & -0.468 & - & 0.40 & 1.143 & - & 1.30 \\
\hline LR chi2 & & 14.24 & & & $25.29 *$ & & & 14.47 & & & 13.36 & & & 17.67 & & & 10.59 & \\
\hline
\end{tabular}


Table: 7.3

ML Estimates of Probit Models (S5 and S6)

\begin{tabular}{|c|c|c|c|c|c|c|c|c|c|c|c|c|c|c|c|c|c|c|}
\hline \multirow[b]{2}{*}{$\begin{array}{l}\text { Independent } \\
\text { variables }\end{array}$} & \multicolumn{9}{|c|}{ Situation 5} & \multicolumn{9}{|c|}{ Situation 6} \\
\hline & \multicolumn{3}{|c|}{$\begin{array}{c}\text { Fulfilment of } \\
\text { "equity axiom" }\end{array}$} & \multicolumn{3}{|c|}{ Switch } & \multicolumn{3}{|c|}{$\begin{array}{c}\text { Strictly } \\
\text { Rawlsian } \\
\end{array}$} & \multicolumn{3}{|c|}{$\begin{array}{l}\text { Fulfilment of } \\
\text { "equity axiom" }\end{array}$} & \multicolumn{3}{|c|}{ Switch } & \multicolumn{3}{|c|}{$\begin{array}{c}\text { Strictly } \\
\text { Rawlsian }\end{array}$} \\
\hline & Coef. & M.E. & $\mathbf{z V}$ & Coef. & M.E. & $\mathbf{z}$ V. & Coef & M.E. & $\mathbf{z V}$. & Coef. & M.E. & $\mathrm{z} \mathrm{V}$ & Coef. & M.E. & $\mathbf{z ~ V .}$ & Coef & M.E. & $\mathrm{z} \mathrm{V}$. \\
\hline$J o b$ & $0.942 *$ & 3.5 & 1.79 & -0.194 & -4.0 & 0.64 & $0.479 *$ & 13.0 & 1.67 & -0.089 & -3.2 & 0.36 & -0.277 & -7.9 & 0.95 & 0.028 & 1.1 & 0.12 \\
\hline Male & 0.558 & 1.8 & 1.35 & 0.038 & 0.8 & 0.14 & 0.184 & 4.9 & 0.69 & -0.163 & -5.9 & 0.67 & -0.087 & -2.4 & 0.32 & -0.142 & -5.6 & 0.60 \\
\hline Male*Job & -0.884 & -3.0 & 1.32 & -0.075 & -1.5 & 0.18 & -0.326 & -8.8 & 0.85 & 0.252 & 9.1 & 0.76 & 0.466 & 13.4 & 1.22 & 0.062 & 2.4 & 0.19 \\
\hline Future 2 & $-5.119 * *$ & -65.9 & 18.30 & 0.017 & 0.3 & 0.06 & -0.276 & -7.3 & 0.94 & 0.157 & 5.7 & 0.69 & 0.316 & 8.9 & 1.20 & 0.045 & 1.7 & 0.20 \\
\hline Parents 2 & -0.067 & -0.2 & 0.13 & -0.011 & -0.2 & 0.03 & -0.075 & -2.0 & 0.24 & -0.321 & -11.6 & 1.14 & -0.396 & -11.2 & 1.43 & 0.091 & 3.6 & 0.34 \\
\hline Parents 3 & -0.201 & -0.6 & 0.35 & -0.414 & -7.1 & 1.00 & 0.238 & 5.8 & 0.63 & $-0.657 *$ & -25.3 & 2.06 & $-0.898 * *$ & -18.7 & 2.44 & 0.075 & 3.0 & 0.24 \\
\hline Parents 4 & -0.111 & -0.3 & 0.19 & 0.026 & 0.5 & 0.07 & -0.177 & -4.9 & 0.51 & -0.062 & -2.3 & 0.19 & -0.016 & -0.5 & 0.05 & 0.071 & 2.8 & 0.24 \\
\hline Sophomore & 0.293 & 0.6 & 0.78 & -0.403 & -7.0 & 1.39 & $0.534 *$ & 12.0 & 2.03 & 0.053 & 1.9 & 0.22 & $-0.510 *$ & -12.3 & 1.86 & $0.410^{*}$ & 16.2 & 1.82 \\
\hline Junior & 0.234 & 0.5 & 0.65 & $-0.472 *$ & -8.2 & 1.67 & $0.505^{*}$ & 11.7 & 2.02 & -0.301 & -11.3 & 1.36 & -0.199 & -5.3 & 0.81 & -0.099 & -3.8 & 0.45 \\
\hline Senior & - & - & - & 0.000 & 0.0 & 0.00 & 0.407 & 9.3 & 1.35 & 0.037 & 1.3 & 0.13 & -0.060 & -1.6 & 0.20 & 0.146 & 5.8 & 0.55 \\
\hline Graduate & 0.474 & 0.9 & 0.77 & -0.133 & -2.5 & 0.30 & 0.505 & 11.3 & 1.24 & 0.158 & 5.7 & 0.45 & 0.424 & 13.1 & 1.12 & -0.061 & -2.4 & 0.18 \\
\hline Constant & $6.921 * *$ & - & 6.26 & -0.085 & - & 0.09 & 0.634 & - & 0.79 & 1.031 & - & 1.60 & 0.637 & - & 0.83 & -0.719 & - & 1.14 \\
\hline LR chi 2 & \multicolumn{3}{|c|}{11.75} & \multicolumn{3}{|c|}{11.39} & \multicolumn{3}{|c|}{16.88} & \multicolumn{3}{|c|}{12.00} & \multicolumn{3}{|c|}{21.80} & \multicolumn{3}{|c|}{9.51} \\
\hline
\end{tabular}

ratio test statistic".

Reference group consists of Female, Future 1, Parents 1, and Freshman.

Level of significance: $* 5 \%$, **1\%.

a Senior dropped and 37 observations not used. 
The maximum likelihood estimation results of eighteen probit models ${ }^{38}$ for the six situations are presented in Table 7.1, 7.2, and 7.3. Similar to the studies of Gaertner and Schwettmann (2007); and Schokkaert and Capeau (1991), the estimated equations reveal a lack of overall explanatory power ${ }^{39}$. The reason for this may be attributed to random distributions of ethical convictions over the population. Fortunately, the lack of overall explanatory power is not an obstacle to interpret the significant effects of the control variables ${ }^{40}$.

Table 7.1, 7.2, and 7.3 show that there is no age effect in any of the situations. Younger students behave no differently than older students regardless of the level of significance ${ }^{41}$. This finding is not compatible with the view/conventional wisdom that "older students generally give greater weight to social concerns" and "more mature students might have had a more sophisticated understanding of the nuances and ambiguities inherent in concepts like fairness" (R. H. Frank et al. 1993: 160).

The effect of job experience upon the perception of justice appears to be statistically significant for both S4 and S5 (except SS5), however, all models (in S4 and S5) are open to some criticism for a lack of explanatory power. Nevertheless, although the obtained results indicate the absence of a clear overall effect of the job experience on decision making; it is possible to say that job experience increases the probability of observing Rawlsian preferences (fulfillment of the "equity axiom" and strictly Rawlsian choices), particularly in S4 and S5.

As can be seen in Table 7.1 and 7.2, male students differ significantly from female students in FS1, FS2 and SS4. However, the latter two models fall short of the critical value. In addition, the sign of the gender effect is negative for the fulfillment scenarios (S1 and S2) and positive for the switch option in S4. Nevertheless, similar to the effect of the variable Job described above, it is difficult to say that a clear gender pattern emerged in regression analyses.

Next, in order to infer how the effect of one independent variable on the dichotomous dependent variable depends on the magnitude of another explanatory variable, I have tried to compute interaction effects in various interacted variables. However, similar to Gaertner and Schwettmann (2007), I detected only one worth mentioning here the effect between gender and job experience. When interaction effect between Male and Job is in question, two particular cases need further explanation in my study ${ }^{42}$.

38 The models are named according to their dependent variables ( $F$ for "Fulfillment of the "equity axiom"”, $S$ for "Switch", and SR for "Strictly Rawlsian") and the situations (S1, S2, S3, S4, S5, and S6) in which they are studied.

39 Only two of the eighteen probit models achieved statistical significance at the 5\% level: (i) FS1: The resulting likelihood ratio test statistic (henceforth LR) is $x^{\mathbf{2}}=25.82$, and (ii) SS3: The resulting LR is $x^{\mathbf{2}}=25.29$. See Table 7.1, 7.2, and 7.3, for all LRs.

40 However, it should be noted that the number of the insignificantly estimated coefficients is not small in the models.

41 The estimates for the coefficient of Age have low standard errors.

42 The first one is SS4 because it is the only model both interacted variables are significant and the second one is FSI because it is the only model the interaction term is significant. Since, as it is known, only looking at the results in a nonlinear probit model can be misleading, I run the Stata command inteff, which "computes the correct marginal effect of a change in two 
First, in SS4 model $^{43}$, for the two-fold interaction term Male*Job there are two possible interpretations. The interaction effect -0.041 means that: (i) the gender difference is four percentage points larger for students with job experience compared to similar students without job experience, or that (ii) the negative effect of being employed on switching is by four percentage points stronger for males than it is for females. Second, in FS $1^{44}$ model, the effect for Male ${ }^{*} J o b$ shows that: (i) for students with job experience the gender difference is twenty percentage points smaller than for similar students without job experience, or (ii) the positive effect of being employed on fulfilling the "equity axiom" is by twenty percentage points stronger for males than it is for women.

The coefficients for future income expectations show that a higher income expectation decreases the probability of observing Rawlsian preferences (fulfillment of the "equity axiom" and strictly Rawlsian choices) significantly only in $\mathrm{S} 5^{45}$. In addition, as Table 7.1 and 7.3 present, a significant marginal effect is manifested solely by the parental background variable Parents 3 in SRS1, FS6 and SS6 ${ }^{46}$. The marginal effect for Parents 3 equal 0.24 in SRS1. The effect of the variable Parents 3 shows that the probability of a student (from a family where the main earner is an employee in the private sector) to fulfill the "equity axiom" is about twenty-five percentage point and to revise her/his decision is about nineteen percentage point, lower than that of reference group in S6. But the point to emphasize here is that all three models (SRS1, FS6 and SS6) suffer from lack of explanatory power. Therefore, as is apparent from the estimations reported in Table 7.1, 7.2, and 7.3, the results suggest that personal features, parental variables and future income expectations play an unimportant role on decision making process when the decision maker needs to make a fairness related decision.

Because this study is designed to investigate the influence of economics teaching on perception of equity and to find out whether it tends to make students more selfish or not, I have a greater incentive to focus on the estimates of CLV that control for class level differences. To explore whether there is an indoctrination effect that economics education has an influence on students' decision making behavior, one needs to summarize the impact of the progression through university upon students' attitude toward Rawlsian approach to equity. To this end, Table 8 is prepared to report the sign of the significant coefficients which allows to control for different level of economics knowledge in each of the eighteen regressions.

The general impression from Table 8 is that economics education does not have much impact on the weight people attach to fairness. A total of eight different models produce statistically

interacted variables for a logit or probit model"(Norton et al. 2004: 154), for the sake of achieving correct statistical inference, For a detailed explanation, see Ai and Norton (2003); and Norton et al. (2004).

43 The resulting $L R$ is $x^{\mathbf{2}}=17.67$

44 The resulting LR is $x^{\mathbf{2}}=25.82$, which is significant at the 5\% level.

45 However, both FS5 and SRS5 fail to achieve statistical significance. The resulting LRs are $x^{\mathbf{2}}=11.75$ and $x^{2}=16.88$

46 Although more than half of the respondents have a parent who is an employee or a civil servant in the public sector, no significant effect is observed for Parents 2 in any of the models run. 
significant estimates for CLV and all but two of these models (FS1 and SS3) have explanatory power. Nevertheless, Table 8 suggests that the year of study has the most apparent effect on sophomores. The number of the significant coefficients is two for juniors and three for seniors. In addition, the absence of significant estimates for the graduate students stands out as an interesting case.

Table 8. The Sign of the Significant Estimates for CLV

\begin{tabular}{|c|c|c|c|c|c|c|c|c|}
\hline & \multicolumn{2}{|c|}{ Sophomore } & \multicolumn{2}{|c|}{ Junior } & \multicolumn{2}{|c|}{ Senior $^{\mathbf{a}, \mathrm{b}}$} & \multicolumn{2}{|c|}{ Graduate } \\
\hline & Model & Sign & Model & Sign & Model & Sign & Model & Sign \\
\hline 1 & FS1* & - & SS5 & - & FS2 & - & & \\
\hline 2 & SS3* & - & SRS5 & + & FS3 & - & & \\
\hline 3 & SRS5 & + & & & SS3* & - & & \\
\hline 4 & SS6 & - & & & & & & \\
\hline 5 & SRS6 & + & & & & & & \\
\hline
\end{tabular}

When the responses to the situations, in which at least two significant estimates are obtained for the same $\mathrm{CLV}^{47}$, are examined, one is likely to be offered the following evaluations: (i) In S6, being a second-year student increases the probability of observing the strictly Rawlsian sequence () and decreases the occurrence of switching behavior. (ii) Similar to the behaviors of the sophomores in S6, the influence of being a junior on choosing the strictly Rawlsian sequence () in S5 is positive. In addition, there is a negative effect of being a third-year student on the revision of the initial decision. (iii) In S3, being a last-year student has a negative influence on fulfilling the "equity axiom" and reduces the probability of revising the initial statement later ${ }^{48}$.

In line with the above-mentioned interpretations, the significance and the sign of the estimates in the models seem to be dependent on the studied case. Therefore, it could be said that the sign of the estimates for CLV does not reveal a consistent pattern.

\section{Concluding Remarks}

There is a common belief that economics teaching has an influence on ethical views of individuals. Although conventional wisdom suggests that economists behave more selfishly than other people, it is possible to find counter examples that can be interpreted as the exhibition of more cooperative behavior by economists. A number of studies have considered how the culture of economics affects the thinking of the economists. The general result is that economists tend to show differences in behavior. In general, regardless of the emphasis placed on the motivation of the researches (e.g., cooperation, inequality, donation, fairness, voluntary contribution, trust, generosity, market mechanism, selfishness, distributional comparisons), there is a common acceptance of the view that the differences seen between economists and non-economists (in particular, in response patterns of economists) may be caused by two effects: (i) The effect of economics training (indoctrination hypothesis): This hypothesis emphasizes that economics training encourages

47 As noted earlier, each situation is tested with three regression models.
48 It is useful to remind that SS3 is a significant model. 
individuals "to emulate the homo economicus found in microeconomics texts" (Bauman and Rose 2011: 318, authors' emphasis) and causes individuals "to act more selfishly" (Frey and Meier 2003: 449). (ii) The effect of self-selection (self-selection hypothesis): A generalization of this hypothesis indicates that individuals "who give more importance to the functioning of the market mechanism self-select into the study of economics" and the supporters of this hypothesis claim that selection into economics is based on individuals" "sentiment on efficiency issues" (Cipriani et al. 2009: 462-463).

The goal of this paper is to examine whether economics education shapes patterns of equity preferences of individuals and how the level of economics knowledge can affect perception of equity. In this context, I have used John Rawls's maximin criterion as a distributive principle in order to evaluate respondents' judgements and perception of the fairness. For the sake of external validity, I have decided to carry out a questionnaire-based approach, originally suggested by Gaertner. To the best of my knowledge, my study represents the first attempt at this scale to analyze decision making processes by using above-mentioned empirical method when distributional issues are of concern to the students at different stages of their education ${ }^{49}$.

The motivation for doing this study is to consider how economics education impacts the perception of equity in a Rawlsian sense -which is one of the fundamental theories of justice- when a realistic survey is involved in process of individual decision making. Because previous studies show that there is disagreement about the impact of both context and education -indoctrination effect- on the preferences, I have decided to research the influence of economics training -indoctrination hypothesis- on distributive justice. To examine the relationship between fairness judgements and the level of the economics education, I have used a survey-type experimental design in which six different situations are investigated.

First of all, the distribution of responses is mostly identical between students from different years. It should be noted that a clear indoctrination effect does not exist. I find only a few significant estimates for CLV, which mostly suffer from lack of explanatory power. As the seniority level of the respondents increases, above-mentioned results reveal only a slight, generally insignificant difference between the classes. Despite the differences between the approaches, this finding is partly compatible with some studies (see e.g. Bauman and Rose 2011; Cappelen et al. 2010; Carter and Irons 1991; R. H. Frank et al. 1993; R. H. Frank et al. 1996; Frey and Meier 2003; Frey and Meier 2005; Frey et al. 1993) while partly conflicting with some others (see e.g. Cipriani et al. 2009; Faravelli 2007/Result 2; Haucap and Just 2010) ${ }^{50}$.

It is possible to explain the relatively high number of significant coefficients for sophomores by a sense of feeling like a "real economist", rather than just a freshman and this sense can lead to a view that they are taking on the role that they have been working towards since beginning their undergraduate instruction ${ }^{51}$. As a result, in the sophomore year, the students might believe that they have to show more differences in decision making process and, if it is the case, one - who is not inclined to accept the indoctrination hypothesis- might expect that the intensity of this

\footnotetext{
49 The pioneering studies of Gaertner and his colleagues mostly have been focused on cultural and intertemporal aspects of equity perceptions.

50 The results obtained by some of these authors indicate that there is evidence of both a learning effect and a selection effect.

51 For an interesting discussion of what it means to be a "real economist", see Lebaron (2001).
} 
feeling would decrease with time due to the seniority. Frey and Meier (2005) reach a similar result in their study on giving behavior. They find that the willingness to donate decreases for economics students entering the main stage from the freshman year, however, for doctoral students in economics, the probability of contributing to the fund increases. They interpret this finding to support the hypothesis that economics education does not make people act more selfishly (Likewise, their 2003 paper (Frey and Meier 2003) offers empirical evidence against the belief that "increased selfishness is due to economics education") and point out that if there is a real learning effect due to the indoctrination of economic education then it should be strongest at the doctoral level. Therefore, they indicate that the possible indoctrination effects of the study must arise because of unobserved heterogeneity. In a related paper, that examines the generosity of the economics students by using administrative data on donations in similar to the above-mentioned studies of Frey and Meier, Bauman and Rose (2011) conclude that there is not an indoctrination effect for economics majors. In addition, Frey et al. (1993) arrive at the same conclusion in their study on the influence of learning and practicing economics on the attitudes of students toward the fairness of price increases. In line with the main findings of Frey and Meier (2005), Cappelen et al. (2010) find only a small difference in the weight attached to fairness between first-year business students and final-year business students. However, they determine that the business graduates attach more weight to fairness considerations than final-year students.

Contrarily, R. H. Frank et al. (1993; 1996) emphasis that economics training makes people less likely to cooperate in social dilemmas -which can be interpreted as a support for the learning hypothesis (Faravelli 2007) ${ }^{52}$, but at the same time, they point out that economists are almost as likely to cooperate as noneconomists under at least some circumstances ${ }^{53}$ and that training in economics has not only antisocial consequences, but also prosocial ones in traditionally communitarian ways. In their paper, Carter and Irons (1991) test the learning hypothesis by allowing for maturation effects ${ }^{54}$ and find that economists are already different at the beginning of their undergraduate study. This finding is compatible with the results of the classical study of Marwell and Ames (1981).

Unfortunately, as noted before, regardless of the similarity/dissimilarity/discrepancy in findings, it is very hard to compare the results of this research with past studies, as a result of the different settings/frameworks/objectives/motivations. In addition, the comparison would be more difficult since this work is a first attempt to examine the stage effect of economics training on fairness in the way used here. However, still it might help to elucidate why economics education doesn't have much influence on the decision making behavior.

Secondly, there are various other factors that can influence the equity perception of each individual and subsequently reveal a need for further examination of the empirical and statistical robustness of the results. The personal factors and socio-demographic position of the respondents can be counted as some of these mentioned. In this study, it is observed that personal features, parental background and future income expectations of the students are not strong variables enough to affect

52 For an objection, see Yezer et al. (1996).

53 For example, in the unlimited version of their prisoner's dilemma experiments.

54 It has been checked whether there is any difference between senior economists and freshman economists. 
the response patterns in most of the situations. However, it is necessary to remember that the interpretation of the coefficient of the interaction between two variables is not straightforward in nonlinear models. Similar to Gaertner and Schwettmann (2007), one finding from this study indicates that the interaction effect between job experience and gender is significant in some cases where the direction of the effect depends on the particular situation being examined.

Finally, the overall explanatory power of the models is generally weak, with LR values ranging from 0.05 to 25.82 . Although this is not an obstacle for the evaluation of the results, it is hard to draw firm/clear-cut conclusions from my observations and this fact means that the results should be approached with caution. Since my primary focus in this research deals with the learning effect, it makes sense to investigate whether the main part of the variation on variables to be dependent upon the stage of education. Moving to the empirical results that I obtain from CLV regressions, the findings suggest that the indoctrination hypothesis may be not: (i) enough to explain the discrepancies between the preferences/perceptions of the individuals; and/or (ii) suitable for the survey data (because of statistical concerns); and/or (iii) tested by using students of different years as subjects in order to check for the effects of economics teaching. However, one thing important is that the low overall explanatory power of the models does not necessarily indicate that there is a selection effect. Because it has already been pointed out that this study is not an attempt to discriminate between the indoctrination and the selection hypothesis. Rather, it seeks only to achieve a better understanding of the learning effect. Therefore one cannot conclude against the indoctrination hypothesis in favor of the self-selection hypothesis.

The Rawlsian approach to distributive justice, in the setting studied here, suggests some opportunities for further investigation. Future research is needed to see if the probit model is stable in different university milieus. It might also be useful to respecify the model allowing for some selection effects. Additionally, another possibility would be to conduct brand-new or just new surveys so as to extend and enrich the data set. By this way, the effect of learning and self-selection on the equity perception can be analyzed simultaneously regardless of the similarity to the method used by the author in this study.

\section{References}

Ai, C. \& E.C. Norton (2003), "Interaction terms in logit and probit models", Economics Letters, 80(1), 123-129.

Amiel, Y. \& F.A. Cowell (1999), Thinking about inequality: Personal judgment and income distributions. Cambridge: Cambridge University Press.

Amiel, Y. \& F.A. Cowell \& W. Gaertner (2009), "To be or not to be involved: a questionnaire-experimental view on Harsanyi's utilitarian ethics", Social Choice and Welfare, 32(2), 299-316.

Bauman, Y. \& E. Rose (2011), "Selection or indoctrination: Why do economics students donate less than the rest?", Journal of Economic Behavior \& Organization, 79(3), 318-327.

Beckman, S.R. \& J.P. Formby \& W.J. Smith \& B. Zheng (2002), "Envy, malice and Pareto efficiency: An experimental examination", Social Choice and Welfare, 19(2), 349-367.

Bellemare, C. \& S. Kröger \& A. Van Soest (2008), "Measuring Inequity Aversion in a Heterogeneous Population Using Experimental Decisions and Subjective Probabilities", Econometrica, 76(4), 815-839.

Bentham, J. (1789), An Introduction to the Principle of Morals and Legislations, reprinted (Oxford, UK: Blackwell, 1948). 
Seniority: A Blessing or A Curse? The Effect of Economics Training on the Perception of Distributive Justice

Benz, M. \& S. Meier (2008), "Do people behave in experiments as in the field?-evidence from donations", Experimental Economics, 11(3), 268-281.

Bernasconi, M. (2002), "How should income be divided? questionnaire evidence from the theory of 'Impartial preferences", Journal of Economics, 9, 163-195.

Bolton, G.E. \& A. Ockenfels (2006), "Inequality aversion, efficiency, and maximin preferences in simple distribution experiments: comment", The American Economic Review, 96(5), 1906-1911.

Bond, D. \& J.C. Park (1991), “An Empirical Test of Rawls's Theory of Justice: A Second Approach, in Korea and the United States", Simulation \& Gaming, 22(4), 443.

Bosmans, K. \& E. Schokkaert (2004), "Social welfare, the veil of ignorance and purely individual risk: An empirical examination", Research on Economic Inequality, 11, 85-114.

Büchner, S. \& G. Coricelli \& B. Greiner (2003), New Experimental Results on the Solidarity Game, (D. d. e. p. U. d. Siena, Trans.): Max-Planck-Inst. for Research into Economic Systems, Strategic Interaction Group.

Cappelen, A.W. \& E.O. Sorensen \& B. Tungodden (2010), "Responsibility for what? Fairness and individual responsibility", European Economic Review, 54(3), 429-441.

Carlsson, F. \& D. Daruvala \& O. Johansson-Stenman (2005), “Are People Inequality-Averse, or Just RiskAverse?", Economica, 72(287), 375-396.

Carlsson, F. \& G. Gupta \& O. Johansson-Stenman (2003), "Choosing from behind a veil of ignorance in India", Applied Economics Letters, 10(13), 825-827.

Carter, J.R. \& M.D. Irons (1991), “Are economists different, and if so, why?”, The Journal of Economic Perspectives, 5(2), 171-177.

Cipriani, G.P. \& D. Lubian \& A. Zago (2009), "Natural born economists?”, Journal of Economic Psychology, $30(3), 455-468$

Cowell, F.A. \& E. Schokkaert (2001), "Risk perceptions and distributional judgments", European Economic Review, 45(4-6), 941-952.

D'Aspremont, C. \& L. Gevers (1977), "Equity and the Informational Basis of Collective Choice", The Review of Economic Studies, 44(2), 199-209.

dela Cruz-Dona, R. \& A. Martina (2000), "Diverse groups agreeing on a system of justice in distribution: Evidence from the Philippines", Journal of Interdisciplinary Economics, 11(1), 35-76.

Deschamps, R. \& L. Gevers (1978), "Leximin and utilitarian rules: A joint characterization”, Journal of Economic Theory, 17(2), 143-163.

Dworkin, R. (1981a), "What is equality? Part 1: Equality of welfare", Philosophy \& Public Affairs, 10(3), 185246.

Dworkin, R. (1981b), "What is equality? Part 2: Equality of resources", Philosophy \& Public Affairs, 10(4), 283345.

Engelmann, D. \& M. Strobel (2004), "Inequality aversion, efficiency, and maximin preferences in simple distribution experiments", The American Economic Review, 94(4), 857-869.

Engelmann, D. \& M. Strobel (2006), "Inequality aversion, efficiency, and maximin preferences in simple distribution experiments: Reply", The American Economic Review, 96(5), 1918-1923.

Faravelli, M. (2007), "How context matters: A survey based experiment on distributive justice", Journal of Public Economics, 91(7-8), 1399-1422.

Fehr, E. \& M. Naef \& K.M. Schmidt (2006), "Inequality aversion, efficiency, and maximin preferences in simple distribution experiments: Comment”, The American Economic Review, 96(5), 1912-1917. 
Fishburn, P.C. (1974), "Lexicographic Orders, Utilities and Decision Rules: A Survey”, Management Science, 20(11), 1442-1471.

Fleurbaey, M. (1998), “Equality among Responsible Individuals. In J.-F. Laslier”, M. Fleurbaey \& N. Gravel \& A. Trannoy (Eds.), Freedom in Economics : New Perspectives in Normative Analysis (pp. 206-234), London: Routledge.

Fleurbaey, M. \& F. Maniquet (2011), “Compensation and Responsibility”, in K.J. Arrow \& A. Sen \& K. Suzumura (Eds.), Handbook of Social Choice and Welfare (Vol. 2, pp. 507-604): Elsevier.

Frank, B. \& G.G. Schulze (2000), “Does economics make citizens corrupt?”, Journal of Economic Behavior \& Organization, 43(1), 101-113.

Frank, R.H. \& T.D. Gilovich \& D.T. Regan (1993), “Does Studying Economics Inhibit Cooperation?”, The Journal of Economic Perspectives, 7(2), 159-171.

Frank, R.H. \& T.D. Gilovich \& D.T. Regan (1996), “Do Economists Make Bad Citizens?”, The Journal of Economic Perspectives, 10(1), 187-192.

Frey, B.S. \& S. Meier (2003), "Are political economists selfish and indoctrinated? Evidence from a natural experiment", Economic Inquiry, 41(3), 448-462.

Frey, B.S. \& S. Meier (2004a), "Pro-social behavior in a natural setting", Journal of Economic Behavior \& Organization, 54(1), 65-88.

Frey, B.S. \& S. Meier (2004b), “Social Comparisons and Pro-Social Behavior: Testing 'Conditional Cooperation' in a Field Experiment", The American Economic Review, 94(5), 1717-1722.

Frey, B.S. \& S. Meier (2005), "Selfish and indoctrinated economists?" European Journal of Law and Economics, 19(2), 165-171.

Frey, B.S. \& W.W. Pommerehne (1993), "On the fairness of pricing--An empirical survey among the general population”, Journal of Economic Behavior \& Organization, 20(3), 295-307.

Frey, B.S. \& W.W. Pommerehne \& B. Gygi (1993), "Economics Indoctrination or Selection? Some Empirical Results", The Journal of Economic Education, 24(3), 271-281.

Frohlich, N. \& J.A. Oppenheimer (1990), "Choosing Justice in Experimental Democracies with Production”, The American Political Science Review, 84(2), 461-477.

Frohlich, N. \& J.A. Oppenheimer (1992), Choosing Justice: An Experimental Approach to Ethical Theory, Berkeley, CA: University of California Press.

Frohlich, N. \& J.A. Oppenheimer (1994), "Preferences for Income Distribution and Distributive Justice: A Window on the Problems of Using Experimental Data in Economics and Ethics", Eastern Economic Journal, 20(2), 147-155.

Frohlich, N. \& J.A. Oppenheimer \& C.L. Eavey (1987a), "Choices of Principles of Distributive Justice in Experimental Groups", American Journal of Political Science, 31(3), 606-636.

Frohlich, N. \& J.A. Oppenheimer \& C.L. Eavey (1987b), "Laboratory Results on Rawls's Distributive Justice", British Journal of Political Science, 17(01), 1-21.

Gaertner, W. (1992), "Distributive judgments", in: W. Gaertner \& M. Klemisch-Ahlert (Eds.), Social Choice and Bargaining Perspectives on Distributive Justice (pp. 22-59), Heidelberg Springer.

Gaertner, W. (1994), "Distributive justice: Theoretical foundations and empirical findings", European Economic Review, 38(3), 711-720.

Gaertner, W. \& J. Jungeilges (2002), "Evaluation via extended orderings: Empirical findings from Western and Eastern Europe", Social Choice and Welfare, 19(1), 29-55.

Gaertner, W. \& J. Jungeilges \& R. Neck (2001), “Cross-cultural equity evaluations: A questionnaire-experimental approach", European Economic Review, 45(4-6), 953-963. 
Seniority: A Blessing or A Curse? The Effect of Economics Training on the Perception of Distributive Justice

Gaertner, W. \& R. Neck \& L. Schwettmann (2011), "Perceptions of Equity across Cultures and over Time: A Questionnaire-Experimental Approach", International Advances in Economic Research, 1-11.

Gaertner, W. \& E. Schokkaert (2011), Empirical Social Choice Questionnaire-Experimental Studies on Distributive Justice, Cambridge: Cambridge University Press.

Gaertner, W. \& L. Schwettmann (2007), "Equity, responsibility and the cultural dimension", Economica, 74(296), 627-649.

Giraud, G. \& C. Renouard (2011), Is the veil of ignorance transparent?, CES Working Paper 2011. 26.

Gneezy, U. \& A. Rustichini (2000), "Pay Enough or Don't Pay at All”, The Quarterly Journal of Economics, 115(3), 791-810.

Guala, F. (2005), The Methodology of Experimental Economics, Cambridge: Cambridge University Press.

Hammond, P.J. (1976), "Equity, Arrow's Conditions, and Rawls' Difference Principle”, Econometrica, 44(4), 793-804.

Harsanyi, J.C. (1953), "Cardinal utility in welfare economics and in the theory of risk-taking", The Journal of Political Economy, 61(5), 434.

Harsanyi, J.C. (1955), "Cardinal welfare, individualistic ethics, and interpersonal comparisons of utility", The Journal of Political Economy, 63(4), 309-321.

Harsanyi, J.C. (1975), "Can the Maximin Principle Serve as a Basis for Morality? A Critique of John Rawls's Theory", The American Political Science Review, 69(2), 594-606.

Harsanyi, J.C. (1977), Rational behavior and bargaining equilibrium, Cambridge, England: Cambridge University Press.

Harsanyi, J.C. (1978), "Bayesian decision theory and utilitarian ethics", The American Economic Review, 68(2), 223-228.

Haucap, J. \& T. Just (2010), "Not guilty? Another look at the nature and nurture of economics students", European Journal of Law and Economics, 29(2), 239-254.

Herne, K. \& M. Suojanen (2004), "The role of information in choices over income distributions", Journal of Conflict Resolution, 48(2), 173.

Hey, J.D. \& C. Pasca (2011), "On choosing a constitution (at least the part relating to the distribution of income)", Applied Economics Letters, 18(13), 1213-1217.

Hu, Y.-A. \& D.-Y. Liu (2003), "Altruism versus Egoism in Human Behavior of Mixed Motives: An Experimental Study", American Journal of Economics and Sociology, 62(4), 677-705.

Isaac, R.M. \& K.F. McCue \& C. Plott (1985), "Public goods provision in an experimental environment", Journal of Public Economics, 26(1), 51-74.

Jackson, M. \& P. Hill (1995), “A Fair Share”, Journal of Theoretical Politics, 7(2), 169-179.

Johannesson, M. \& U.G. Gerdtham (1995), "A pilot test of using the veil of ignorance approach to estimate a social welfare function for income", Applied Economics Letters, 2(10), 400-402.

Johansson-Stenman, O. \& F. Carlsson \& D. Daruvala (2002), "Measuring Future Grandparents' Preferences for Equality and Relative Standing", The Economic Journal, 112(479), 362-383.

Jungeilges, J. \& T. Theisen (2008), “A comparative study of equity judgements in Lithuania and Norway", Journal of Socio-Economics, 37(3), 1090-1118.

Jungeilges, J. \& T. Theisen (2011), "State dependence in sequential equity judgements", Social Choice and Welfare, 37(1), 97-119.

Kagel, J. \& C. Kim \& D. Moser (1992), 'Fairness' in ultimatum games with asymmetric information and asymmetric payoffs, Pittsburgh: University of Pittsburgh. 
Kariv, S. \& W.R. Zame (2008), Piercing the Veil of Ignorance, Mimeo, <http://emlab.berkeley.edu/ kariv/KZ_I.pdf.>, 14 August 2013.

Kirchgassner, G. (2005), “(Why) are economists different?”, European Journal of Political Economy, 21(3), 543562.

Konow, J. (2000), "Fair Shares: Accountability and Cognitive Dissonance in Allocation Decisions”, The American Economic Review, 90(4), 1072-1091.

Konow, J. (2001), "Fair and square: the four sides of distributive justice", Journal of Economic Behavior \& Organization, 46(2), 137-164.

Konow, J. (2003), "Which Is the Fairest One of All? A Positive Analysis of Justice Theories", Journal of Economic Literature, 41(4), 1188-1239.

Laband, D.N. \& R.O. Beil (1999), “Are economists more selfish than other 'social' scientists?”, Public Choice, 100(1), 85-101.

Lebaron, F. (2001), "Economists and The Economics Order The field of economists and the field of power in France", European Societies, 3(1), 91-110.

Ledyard, J.O. (1995), "Public goods: A survey of experimental research", in: J.H. Kagel \& A.E. Roth (Eds.), The Handbook of Experimental Economics (pp. 111-194), Princeton: Princeton University Press.

Lissowski, G. \& T. Tyszka \& W. Okrasa (1991), "Principles of Distributive Justice: Experiments in Poland and America", The Journal of Conflict Resolution, 35(1), 98-119.

Loewenstein, G. (1999), "Experimental Economics from the Vantage-Point of Behavioural Economics", The Economic Journal, 109(453), F25-F34.

Marwell, G. \& R.E. Ames (1981), "Economists free ride, does anyone else?: Experiments on the provision of public goods", IV. Journal of Public Economics, 15(3), 295-310.

Mill, J.S. (1861), Considerations on Representative Government, reprinted (South Bend, Ind.: Gateway Editions, 1962).

Norton, E.C. \& H. Wang \& C. Ai (2004), "Computing interaction effects and standard errors in logit and probit models", The Stata Journal, 4(2), 154-167.

Ockenfels, A. \& J. Weimann (1999), “Types and patterns: an experimental East-West-German comparison of cooperation and solidarity", Journal of Public Economics, 71(2), 275-287.

Oleson, P.E. (2001), An experimental examination of alternative theories of distributive justice and economic fairness, (Ph.D. dissertation), University of Arizona, Tucson, AZ.

Rawls, J. (1971), A Theory of Justice, Cambridge, MA: Harvard University Press.

Rawls, J. (1974), "Some Reasons for the Maximin Criterion", The American Economic Review, 64(2), 141-146.

Read, D. (2005), "Monetary incentives, what are they good for?", Journal of Economic Methodology, 12(2), 265276.

Rubinstein, A. (2006), "A Sceptic's Comment on the Study of Economics", The Economic Journal, 116(510), C1C9.

Schildberg-Hörisch, H. (2010), "Is the veil of ignorance only a concept about risk? An experiment", Journal of Public Economics, 94(11-12), 1062-1066.

Schokkaert, E. \& B. Capeau (1991), "Interindividual Differences in Opinions about Distributive Justice”, Kyklos, 44(3), 325-345.

Schokkaert, E. \& K. Devooght (2003), "Responsibility-sensitive fair compensation in different cultures", Social Choice and Welfare, 21(2), 207-242.

Schokkaert, E. \& B. Overlaet (1989), "Moral intuitions and economic models of distributive justice", Social Choice and Welfare, 6(1), 19-31. 
Seniority: A Blessing or A Curse? The Effect of Economics Training on the Perception of Distributive Justice

Selten, R. \& A. Ockenfels (1998), “An experimental solidarity game”, Journal of Economic Behavior \& Organization, 34(4), 517-539.

Sen, A. (1973), On economic inequality. Oxford: Clarendon Press.

Sen, A. (2000), "Social justice and the distribution of income", in A.B. Atkinson \& F. Bourguignon (Eds.), Handbook of income distribution (Vol. 1, pp. 59-85): Elsevier.

Swope, K. \& J. Cadigan \& P. Schmitt \& R. Shupp (2008), "Social Position and Distributive Justice: Experimental Evidence", Southern Economic Journal, 74(3), 811-818.

Traub, S. \& C. Seidl \& U. Schmidt (2009), "An experimental study on individual choice, social welfare, and social preferences", European Economic Review, 53(4), 385-400.

Traub, S. \& C. Seidl \& U. Schmidt \& M.V. Levati (2005), "Friedman, Harsanyi, Rawls, Boulding-or somebody else? An experimental investigation of distributive justice", Social Choice and Welfare, 24(2), 283309.

Vickrey, W. (1945), "Measuring Marginal Utility by Reactions to Risk", Econometrica, 13(4), 319-333.

Vickrey, W. (1960), "Utility, Strategy, and Social Decision Rules”, The Quarterly Journal of Economics, 74(4), 507-535.

Vieider, F. (2011), "Separating real incentives and accountability", Experimental Economics, 14(4), 507-518.

Yaari, M.E. \& M. Bar-Hillel (1984), "On dividing justly”, Social Choice and Welfare, 1(1), 1-24.

Yezer, A.M. \& R.S. Goldfarb \& P.J. Poppen (1996), "Does Studying Economics Discourage Cooperation? Watch What we do, not what we say or How we Play", The Journal of Economic Perspectives, 10(1), 177186.

Zsolnai, L. (2003), "Honesty versus Cooperation: A Reinterpretation of the Moral Behavior of Economics Students", American Journal of Economics and Sociology, 62(4), 707-712. 
İbrahim Erdem SEÇiLMIŞ̧

152 